|Araştırma Makalesi / Research Article |

\title{
Özel Gereksinimli Çocuklar İçin Tasarlanan Elektronik Performans Destek Sisteminin Kâğıt Prototip Kullanılabilirliği ${ }^{1}$
}

\section{Paper Prototype Usability of Electronic Performance Support System Designed For Children With Special Needs}

\section{Tayfun Akın², Yasemin Koçak Usluel ${ }^{3}$}

\author{
Anahtar Kelimeler \\ erken çocukluk özel \\ eğitimi \\ kağıt protoip \\ kullanılabilirlik \\ elektronik performans \\ destek sistemi
}

\section{Keywords \\ early childhood special education \\ paper prototype \\ usability \\ electronic performance support system}

Başvuru Tarihi/Received 03.07.2018

Kabul Tarihi /Accepted 25.11.2019
Öz

Makalenin erken çocukluk aşamasında gelişim ile ilgili kritik dönemler fazladır. Bu nedenle özel eğitime ihtiyaç duyan çocukların gelişimlerini desteklemek için çeşitli yollar arandığı bilinmektedir. Buradan hareketle erken çocukluk özel eğitiminde erken müdahaleyi desteklemek amacıyla 0-6 yaş arası çocukların gelişimlerini izleyip raporlamaya ve öğretmenlerin veya uygulayıcıların performanslarını desteklemeye yönelik bir Elektronik Performans Destek Sistemine (EPDS) gereksinim olduğu belirlenmiştir. Bu çalışmada, geliştirilmesi planlanan EPDS'nin kullanılabilirlik çalışmalarından ilki olan kâğıt prototip kullanılabilirlik çalışması, süreç ve sonuçlarıyla paylaşılmıştır. Bilindiği gibi tasarım sürecinin başında, kâğıt prototiplerin hızlıca üretilmesi, kullanıcı deneyimlerinin göz önünde bulundurularak bir sistemde değiştirilmesi gereken yerlerin hızlı ve ucuz bir şekilde öğrenilmesine katkı sağlamaktadır. Öncelikle, EPDS’nin tasarlanabilmesi için sekiz kişi ile ihtiyaç analizi çalışması yapılmıştır. Kâğıt üzerinde tasarlanan EPDS'nin kullanılabilirlik çalışması için beşi özel eğitim kurumu çalışanı bir tanesi de uzman tasarımcıdan oluşan altı kişi ile çalışımıştır. Veriler yarı yapılandırılmış görüşme formu, video ve ses kayıtları ile toplanmıştır. Toplanan veriler, görev tamamlama durumu temel alınarak analiz edilmiştir. Analiz sonucunda görevlerin uygulanması ve tamamlanması için yapılması gereken değişiklikler belirlenerek, öneriler ortaya konulmuştur. Alanyazında da belirtildiği gibi, sistemde, danışman/uzman sistem, öğretimsel sistem ve kişiselleştirilmiş araçlar önemli bileşenler olarak ortaya çıkmıştır. Sonuç olarak bu çalışma ile gerçek kullanıcıların gereksinimleri doğrultusunda, erken çocukluk özel eğitimine yönelik erken müdahale konusunda geliştirilmesi düşünülen sistemin tasarım aşamasının temeli oluşturulmuştur.

\section{Abstract}

There are many critical periods related to development in the early childhood stage. Accordingly, it is also known that various methods are being sought out in order to support the development of children that need special education. So, the need for an Electronic Performance Support System (EPSS) that will report and monitor the development of children aged between 0-6 and to support the performance of the teachers or the implementers with the aim of supporting early intervention in early childhood special education was detected. The paper prototype usability study which is the first usability study for the EPDS that is being planned to be developed is shared with the process and the results. As it is known, at the beginning of the design process, the rapid production of paper prototypes contributes to the quick and cheap learning of the places that need to be changed in a system considering the user experiences. Initially, a need analysis study was carried out with eight people in order to design the EPSS. Six people worked on the usability of the EPSS design on paper, five of the people were special education institution employees and the other was an expert designer. The data was collected with a semistructured interview form, as well as video and audio recordings. The collected data were analyzed based on the status of task completion. As a result of the analysis, the necessary changes for the implementation and completion of the tasks were determined and suggestions were put forward. As indicated in the relevant literature, the adviser/expert system, instructional system and personalized tools emerged as significant components for the main system. In conclusion, this study forms the basis for the designing stage for the development of a system that will satisfy user needs with regards to early intervention for early childhood education.

\footnotetext{
${ }^{1}$ Bu çalışma, ikinci yazar danışmanlığında, birinci yazarın doktora tezinden üretilmiştir.

${ }^{2}$ Siirt Üniversitesi, Eğitim Fakültesi, Bilgisayar ve Öğretim Teknolojileri Eğitimi Bölümü, Siirt, Türkiye; https://orcid.org/0000-0001-5364-6102

${ }^{3}$ Hacettepe Üniversitesi, Eğitim Fakültesi, Bilgisayar ve Öğretim Teknolojileri Eğitimi Bölümü, Ankara, Türkiye; https://orcid.org/0000-0002-6147-3333
} 
Extended Abstract

\section{Introduction}

Early childhood is a critical period in which personalities are shaped as children develop rapidly in terms of mental, physical and social aspects (Efevbera, McCoy, Wuermli and Betancourt, 2017). For this reason, the monitoring and reporting of child development in order to provide appropriate services and to make the necessary early interventions for the children in this period is considered as an important part of the early childhood education period. Considering the high cost, the inadequacy of the sources and the increasing service demands, it is stated in the literature that effective and safe systems are needed and various approaches on special education field are looked for in terms of monitoring the developments and offering proper interventions (Walker, Carta, Greenwood ve Buzhardt, 2008; Buzhardt, Walker, Greenwood ve HeitzmanPowell, 2012). On the other hand, it is known that in today's world, technology has features that can support teaching-learning activities and the performance of the teacher in the process of monitoring and reporting the development in special education. It can be said that the teacher is not only an individual who enters the classroom and supports the acquisition of the related goals, but also responsible for the efficient execution of the education and training activities as a whole. In this sense, it can be argued that the electronic performance support system (EPSS) can contribute to supporting the process and the performance of the teachers.

EPSS is defined as the systems that provide support for performance and learning when there is a need (Gery, 1991). Therefore, it can be said that the main purpose of the EPSS is to provide the necessary support to the user.

In an EPSS designed to support users, the interaction of users with the system is important. It can be said that the usability becomes prominent when it comes to human interaction with a system. Looking at the usability explanations, it is seen that usability has three main elements; effectiveness, efficiency and satisfaction. Effectiveness, accuracy and lack of users in reaching the target; efficiency, resources used to reach the target, time spent, cost, human resource; and satisfaction, the level of meeting the needs and expectations of the user of the physical, cognitive, and emotional reactions of the user resulting from the use of a system, product or service (Çağıltay, 2011; ISO 9241-11, 2017).

When the literature is looked through, it is seen that there are different usability evaluation methods. It is stated that in addition to the eye tracking method which is prominent with the current technological developments, many different methods and techniques are used like expert evaluation, observation, questionnaire, think aloud method, log records, paper prototypes, animation, joint exploration, card sorting, based design, focus group research, video and audio recording, and usability tests (Yeniad, Mazman, Tüzün ve Akbal, 2011; Budak, 2016). The choice of method and technique that will be used to evaluate the usability of a product is asserted to be affected by the aim, the time, the budget and the number of available users of the study (Ekici, Arslan ve Tüzün, 2016).

In this study, with the aim of supporting early intervention in early childhood special education, the usability of EPSS paper prototype was examined to report and monitor the development of children aged between $0-6$ and to support the performance of the teachers or the implementers.

\section{Method}

Three steps were followed in the study; need analysis and design, implementation and evaluation. Needs analysis has been carried out, taking into account the wishes and capabilities of real users during the design phase of the EPSS. As a result of unstructured interviews with a participant who is a manager and a specialist in a special education institution, a paper prototype draft of the system was created. Then, during the development process of this paper prototype draft, needs analysis was conducted with teachers, managers and specialists working in the field of special education. In the implementation phase, the paper prototype of the system was prepared and the usability test was applied to 10 different tasks in accordance with this system. The data was collected by semistructured interview form, video and audio recordings.

Qualitative data analysis program was used for needs analysis data and the themes, codes and categories were created. The data of the usability test were also analyzed by following the steps below;

1. Possible steps to follow to complete a task were identified.

2. For each participant, video recordings and audio recordings showing which task they did and how they did were examined and described

3. The task completion status of the participants were summarized in a separate table.

4. Finally, suggestions were offered to do some changes in the system according to the completion status of the task in the process.

\section{Result and Discussion}

As a result of the needs analysis, it was decided to add consultant and instructional system component to the system. As a result of the paper usability assessment, the problem of searching the student name and surname and left menu design areas were determined as two basic problems. Suggestions are presented considering these problems and the mistakes of users. 
GíRiş

Özel eğitimde teknolojinin kullanımı ile hem öğrenme ve öğretme süreçlerinde, hem de performans ve becerilerde olumlu gelişmelerin olduğu belirlenmiştir (Avcıoğlu, 2013; Campigotto, McEwen ve Epp, 2013; Falth, Gustafson, Tjus, Heimann ve Svensson, 2013; Karal, 2009; Ploessl ve Rock, 2014; Polat, Adıgüzel ve Akgün, 2012; Rock, vd., 2014; Hollingsworth ve Lim, 2015; Vuran ve Gül, 2012). Bu durum özel eğitimde teknoloji destekli çalışmaların artmasını beraberinde getirmiştir (Brock ve Carter, 2015; Creech-Galloway, Collins, Knight ve Bausch, 2013; Hollingsworth ve Lim, 2015; Kennedy, Thomas, Aronin, Newton ve Lloyd, 2014; Rama ve Kontu, 2012; Rock, vd., 2014). Özel eğitimde teknoloji kullanımı ile ilgili alanyazın incelendiğinde, özellikle otizmli ve öğrenme güçlüğü olan bireylerle video teknolojilerinin, erken çocukluk özel eğitiminde ve genel olarak özel eğitimde ise web teknolojilerinin kullanıldığı belirlenmiştir (Andreassen ve Braten, 2013; Coogle, Rahn ve Ottley, 2015; Hollingsworth, ve Lim, 2015; Lee, Mohamed ve Altamimi, 2015; Polat, Adiguzel ve Akgun, 2012; Wilder, Magnusson ve Hanson, 2015). Bunların yanı sıra alanyazında özel eğitim bağlamında mobil teknolojiler, bilgisayar destekli teknolojiler, oyun, internet teknolojileri ve çeşitli yazılımların kullanıldığı çalışmaların olduğu da görülmektedir (Campigotto, McEwen ve Epp, 2013; Hong, Ganz, Gilliland ve Ninci, 2014; Marino ve Beecher, 2010).

Erken çocukluk dönemi, çocukların zihinsel, fiziksel ve sosyal yönden hızlı bir şekilde gelişim gösterirken kişiliklerinin de şekillendiği kritik bir dönemdir (Efevbera, McCoy, Wuermli ve Betancourt, 2017). Bu nedenle bu dönemdeki çocuklara uygun hizmetlerin sağlanması ve gerekli erken müdahalelerin yapılması adına çocukların gelişimlerinin izlenmesi ve raporlanması, erken çocukluk eğitim sürecinin her zaman önemli bir parçası olarak kabul edilmektedir. Maliyetlerin yüksek olması, kaynakların yetersiz olması ve artan hizmet talebi dikkate alındığında gelişimlerin izlenmesi ve uygun müdahalenin sunulması konusunda özel eğitim alanında çeşitli yollar arandığı ve etkili, güvenilir sistemlere gereksinim olduğu alanyazında dile getirilmektedir (Buzhardt, Walker, Greenwood ve Heitzman-Powell, 2012; Walker, Carta, Greenwood ve Buzhardt, 2008). Öte yandan bugün gelinen noktada teknolojilerin özel eğitimde gelişim izleme ve raporlama sürecinde, öğrenme öğretme etkinliklerini ve öğretmenin performansını destekleyebilecek özelliklere sahip olduğu bilinmektedir. Bu anlamda Elektronik Performans Destek Sistemi (EPDS)'nin süreci kolaylaştırma ve öğretmenlerin performansını destekleme konusunda katkı sağlayabileceği ileri sürülebilir.

\section{Elektronik Performans Destek Sistemi}

EPDS, ihtiyaç duyulduğunda, performans ve öğrenme için gerekli desteği sağlayan sistemler olarak tanımlanmaktadır (Gery, 1991). Çağıltay (2006, s.3) EPDS ile ilgili farklı tanımları analiz ederek, EPDS’nin tümleşik yazılım bileşenlerini içeren, bir organizasyonun bilgi yönetim sisteminin parçası olan, kullanıcı kontrollü ve kullanımı kolay, doğru zamanda, doğru yerde, doğru miktarda ve türde destek sağlayan bir sistem olması gerektiğini ifade etmiştir.

Bir EPDS'de bulunması gereken özelliklere ek olarak, sistemde hangi bileşenlerin olması gerektiği konusunda alanyazında çeşitlilik olduğu; farklı yazarların farklı açıklamalarının olduğu (Barker ve Banerji, 1995; Chang, 2004; McKay ve Wager, 2007; Raybould, 1990; Reigeluth, 1999), ancak bazı noktalarda da birleştikleri dikkati çekmektedir. Bu bağlamda alanyazında EPDS ile ilgili çalışmalar taranarak, temel beş çalışmada EPDS bileşenlerinin nasıl ele alındığı analiz edilmiştir. Analiz sonucu Tablo 1'de verilmiştir.

Tablo 1. EPDS bileşenleri

\begin{tabular}{|c|c|c|c|c|c|}
\hline & Raybould (1990) & $\begin{array}{c}\text { Barker ve Banerji } \\
\text { (1995) }\end{array}$ & Reigeluth (1999) & Chang (2004) & $\begin{array}{c}\text { McKay ve Wager } \\
\text { (2007) }\end{array}$ \\
\hline Veritabanı & $\checkmark$ & $\checkmark$ & $\checkmark$ & $\checkmark$ & $\checkmark$ \\
\hline Arayüz & & $\checkmark$ & & $\checkmark$ & \\
\hline Danışman Sistem & $\checkmark$ & & & $\checkmark$ & \\
\hline Uzman Sistem & & & $\checkmark$ & & $\checkmark$ \\
\hline Çevrimiçi Yardım & & & & $\checkmark$ & \\
\hline Öğretimsel Sistem & $\checkmark$ & & $\checkmark$ & $\checkmark$ & $\checkmark$ \\
\hline Araçlar & & $\checkmark$ & $\checkmark$ & $\checkmark$ & $\checkmark$ \\
\hline Özel Uygulama Alanı & & $\checkmark$ & & & \\
\hline
\end{tabular}

Tablo 1'de gösterilen bileşenler aşağıda sırasıyla açıklanmıştır.

Veri tabanı: Veritabanı bütün yazarlar tarafından bir EPDS'de olması gereken bileşen olarak belirtilmiştir. Görevin gerçekleştirilmesi için gerekli bütün bilgileri barındıran alan olarak ifade edilmiştir. Bazı yazarların veritabanı ve arayüzü tek bir bileşen olarak ele aldığı (Barker ve Banerji, 1995), bazı yazarların ise arayüzü ayrı bir bileşen olarak ele aldığı dikkati çekmektedir (Chang, 2004).

Arayüz: Arayüz, kullanıcının sistemde yer alan bileşenlere erişmeyi ve bu bileşenler arasında gezinmeyi sağlayan bölüm olarak tanımlamıştır (Chang, 2004).

Danışman/Uzman sistem: Uzman sistem ve danışman sistem ile ilgili farklı yazarların yaptığı tanımlar incelendiğinde (Chang, 2004; McKay ve Wager, 2007; Raybould, 1990; Reigeluth, 1999) uzman ve danışman sistemin benzer roller üstlendiği ve rutin görev esnasında kullanıcıya görevin nasıl gerçekleştirilebileceğine ilişkin destek sağlayan sistem olarak tanımlandığı belirlenmiştir. 
Öğretimsel sistem: Öğretimsel sistem bütün yazarlar tarafından bir EPDS'de olması gereken bileşen olarak belirtilmiş ve EPDS'nin kullanımına yönelik olarak öğrenme deneyimlerini destekleyen sistem olarak tanımlandığı belirlenmiştir (Chang, 2004; Reigeluth, 1999).

Araç: Araçlar konusunda bütün yazarların (Tablo 1) değişik görevlerin gerçekleştirilmesi sırasında ihtiyaç duyulabilecek, e-posta, grafik araçları, hesap makinesi ve göreve özel uygulamalar gibi araçları dile getirdikleri görülmüştür.

Özel eğitim, erken çocukluk ve okulöncesi eğitimi bağlamında EPDS ile ilgili alanyazın tarandığında sınırlı sayıda çalışmanın olduğu dikkati çekmiştir. Çalışmalar incelendiğinde hem öğretmenler hem de öğrencilerin desteklenmesine yönelik geliştirilen ve araştırılan EPDS'lerin sonuçlarının paylaşıldığı belirlenmiştir. Bu anlamda öğretmenlerin veya eğitimcilerin performanslarını desteklemeye yönelik kullanılan EPDS'ler ile ilgili araştırmalar kronolojik olarak aşağıda verilmiştir.

Coleman, Cramer, Park ve Bell (2015), yaptıkları çalışmada, sanat eğitimcilerinin, resim dersinde fiziksel, duyusal ve çoklu engelli öğrencilerin gereksinimlerini karşılamak için özel eğitim personelinin yardımcı teknoloji kullanımlarını incelemeyi amaçlamıştır. Araştırma sonucuna göre öğretmenlerin yardımcı teknolojilerden yararlanmadıkları ortaya çıkmıştır. Bu nedenle yardımcı teknoloji kullanımı konusunda hazırık yapılması gerektiği önerilmiştir.

Schmid, Miodrag ve Francesco (2008), ilköğretim öğrencileri ile bire bir çalışırken öğretmenlere rehberlik edecek şekilde, ders sürecini daha etkin ve verimli hale getirmek için bir EPDS kullanılarak, bunun etkilerini araştırmışlardır. Çalışma, ebeveynlerinin gönüllü olarak katıldığı 4-5 yaş arasındaki çocuklar ile yürütülmüştür. Araştırma sonucunda, EPDS'nin, temel beceri kazanımında başarıyı artırmada önemli derecede etkisi olduğu ortaya çıkmıştır. Öğretmenler, EPDS’nin derslerini canlandırdığı ve öğrencinin motivasyonunu artırmada çok önemli rol oynadığını ifade etmişlerdir.

Hung ve Lockard (2007), sınıf davranış yönetimi için müdahale stratejilerinin geliştirilmesinde öğretmenlerin performansını desteklemeye yönelik matris destekli performans sistemi (MAPS) geliştirerek, sistemin tasarım ve etkisini araştırdıkları çalışmada, MAPS'ın kabulünde, kullanışlı ve pratik olmasının etkili olduğunu ortaya koymuşlardır. Sistemin hem öğretmenler hem de ebeveynler arasında bilgi alışverişini kolaylaştırmasının öğrenme deneyimlerini geliştirdiği belirtilmiştir.

Paschall (2004), tarafından yürütülen araştırmada, özel eğitim öğretmenlerinin özel ihtiyaçları olan öğrencilerine yönelik bireyselleştirilmiş eğitim planları üretmek için kullandıkları EPDS'nin uygulaması değerlendirilmiştir. Değerlendirme sonucunda, bireyselleştirilmiş eğitim planı üretmede sistemin verimli olduğu, fakat veri girişi ve aracın nasıl kullanılacağı konusunda zaman kaybı yaşandığı ortaya çıkmıştır.

Araştırmaların sonuçlarına bakıldığında EPDS'lerin öğretmenlerin performanslarına katkı sağladığı ve motivasyonlarına olumlu anlamda etki ettiği görülmektedir. Bunun yanı sıra EPDS kullanımı ile ilgili bazı noktalara dikkat edilmesi gerektiği ortaya çıkmıştır. Teknoloji kullanım becerisi düşük olan öğretmenlere bu tür sistemlerin kullanımı ile ilgili sunulacak desteğin EPDS kullanımını etkilediği bilinmektedir. Özellikle EPDS’nin kullanımı konusunda öğretmenlere yardımcı olacak bileşenlerin önemli olduğu belirlenmiştir.

Özel eğitime ihtiyaç duyan öğrenciler veya erken çocukluk dönemindeki çocuklar ile ilgili yürütülen çalışmalara bakıldığında; Hollingsworth ve Lim (2015), erken çocukluk alanında okuyan lisans öğrencileriyle yürüttüğü çalışmada web tabanlı bir sistem aracılığıyla öğretimin etkiliği ve öğrencilerin öğrenmeye bakış açılarını incelemiştir. Araştırma sonucuna göre web tabanlı modüllerin öğrencilerin bilgi ve yeterlilik düzeylerine, belirli kanıt temelli uygulamaların yazılı açıklamaları ve tamamlanan ödevler üzerinde etkili olduğu belirtilmiştir. Öğrenciler videolar ve gerçekçi uygulamaların en kullanışlı modül olduğunu ifade etmişlerdir.

Mitchem, Fitzgerald, Miller ve Hollingsead (2013), EPDS'nin, eğitim ve uygulamasında, hedeflenen amaçlara ulaşmadaki etkisini araştırdıkları, özel gereksinimli öğrencilerle yürüttükleri çalışmada, özel gereksinimli öğrenciler için eğitim ortamına müdahale edildiğinde bir iyileşme olduğunu belirlemişlerdir.

Cullen, Richards ve Frank (2008), bir kelime işlemci ve kelime tahmin programının engelli öğrencilerin yazma becerileri üzerine etkisini araştırmışlardır. Özel eğitime ihtiyaç duyan ve beşinci sınıfa giden yedi öğrenci ile yapılan çalışma sonucuna göre öğrencilerin ikisi hariç diğerlerinde üretilen kelime sayılarında artış olduğu belirlenmiştir.

Mitchem, Kight, Fitzgerald, Koury ve Boonseng (2007), orta dereceli yetersiz öğrencilerin sınıf ortamında ve ev ortamlarında bağımsız olarak kullanılmak üzere tasarlanan bir EPDS olan StrategyTools ${ }^{\mathrm{TM}}$ uygulamasının, kullanılabilirliğini ve etkililiğini araştırmışlardır. Araştırma sonucunda öğrenciler ve öğretmenler yazılımı yararıı bulduklarını belirtmişlerdir. Öğrenciler, yazılımı kullanmanın bir sonucu olarak akademik, davranış ve geçiş alanlarında kendilerine katkı sağladığını dile getirmişlerdir.

EPDS ile ilgili yapılan çalışmalar incelendiğinde hem öğretmenlerin hem de öğrencilerin performanslarına destek sağladı̆̆ı görülmektedir. Bu anlamda kullanıcıların intiyaçları doğrultusunda EPDS'lerin uygun bileşenlerinin belirlenmesinin tarafların performansına katkı sağlayacağı ileri sürülebilir. Aynı zamanda geliştirilen sistemlerin kullanıcılar için kullanılabilirliğinin yüksek olması da bu tür sistemlerin kullanımlarını ve kabulünü daha da kolaylaştırmaktadır. Alanyazın incelendiğinde bütüncül bir bakış açısıyla hem çocukların gelişimlerini izleyip raporlamaya yönelik, hem de öğretmenlerin veya uygulayıcıların performanslarını desteklemeye yönelik bir EPDS'nin geliştirilmediği ve buna yönelik bir araştırmanın raporlanmadığı dikkati çekmiştir. Buradan hareketle birinci adımını kâğıt üzerinde kullanılabilirlik çalışmasının oluşturduğu, tasarlanıp geliştirilmesi düşünülen EPDS'nin bir çocuğun gelişimini izleyip raporlama konusunda öğrenci, öğretmen, uygulayıcılar ve aileye destek sağlayabileceği ileri sürülebilir.

Kullanıcıların sistem ile iletişimi noktasında bir sistemin veya ürünün başarılı olabilmesi için kullanılabilir olması gerektiği ifade edilmektedir (Menzi-Cetin, Alemdağ, Tüzün ve Yıldız, 2017; Pero, 2003). Bir sistemin kullanılabilir olmasının yanı sıra kullanılabilirlik

| Kastamonu Eğitim Dergisi, 2020, Vol. 28, No. 3| 
değerlendirmesinin ne zaman yapılacağının da önemli olduğu bilinmektedir. Nitekim Nielsen (1993), tasarımcıların, sistemi geliştirme aşamasının başlarında sistemin kullanılabilirliğinin değerlendirmesinin, sistemin kullanımını ya da kabulünü arttıracağını belirtmiştir. Aşağıda kullanılabilirlik ile ilgili açıklamalara yer verilmiştir.

\section{Kullanılabilirlik}

İnsan bilgisayar etkileşiminde insanın, etkileşimli sistemlerin merkezinde yer aldığı ve bilgisayarların kolay ve kullanışlı olabilmesine odaklanıldığı ifade edilmektedir (Dix, 2009; Dix, Finlay, Abowd ve Beale, 2004). Bu noktada "kullanılabilirliğin" insan bilgisayar etkileşiminde kritik öğe olarak rol oynadığı ileri sürülebilir. Kullanılabilirlik, web siteleri, yazılımlar, cihazlar veya uygulamalar da dâhil olmak üzere ürün veya sistemlerle etkileşimde bulunulduğunda bir kullanıcının deneyiminin kalitesi olarak tanımlanmaktadır (Usability, 2017). Uluslararası Standartlar Örgütü (ISO) kullanılabilirliğin boyutlarını ortaya koyarak; bir ürünün kullanıcılar tarafından bir amaç doğrultusunda etkili, verimli ve memnun edici bir şekilde kullanılmasını kullanılabilirlik olarak tanımlamıştır. Çağıltay (2011), ISO tanımına ek olarak etkililik, verimlilik ve memnuniyet konusunda kullanıcılara belirlenen ortamlarda görevler verilmesi gerektiğini belirtmiştir. Bir başka çalışmada ise destek ve eğitime vurgu yapıldığı; kullanılabilirliğin "hedef kitlenin, destek veya eğitim aldıktan sonra, belirli görevleri yerine getirmek için sistemin etkin ve kolay kullanılabilmesi" olarak tanımlandığı görülmektedir (Shackel, 2009). Tanımlar incelendiğinde kullanılabilirliğin etkililik, verimlilik ve memnuniyet olmak üzere üç temel unsuru olduğu görülmektedir. Etkililik, kullanıcıların hedefe ulaşmadaki doğruluk ve eksikliği; verimlilik, hedefe ulaşırken kullanılan kaynaklar, harcanan süre, maliyet, insan kaynağı; memnuniyet bir sistemin, ürünün veya hizmetin kullanımından kaynaklanan kullanııının fiziksel, bilişsel ve duygusal tepkilerinin kullanıcının ihtiyaç ve beklentilerini karşılama derecesi olarak açıklanmıştır (Çağıltay, 2011; ISO 9241-11, 2017). Buradan hareketle bir ürünün kullanılabilirliğinin değerlendirilmesinde amaç, zaman, bütçe, ulaşılabilecek kullanıcı sayısı, sahip olunan kaynaklar ve bu ölçütler doğrultusunda en uygun yöntem veya tekniğin belirlenmesinin gerektiği ileri sürülebilir (Ekici, Arslan ve Tüzün, 2016).

Bir web sitesinin tasarlanması ve geliştirilmesi aşamasında kullanılabilirlik değerlendirmesi, araştırma kapsamında var olan yazılım veya donanımın kullanımı sırasında kullanıcıların gözlemlenmesi ve etkileşimleri sonucu ortaya çıkan sıkıntıları, sorunları gidermeye yönelik yapılacak iyileştirmelerdir. Bir başka amaç ise eğitim süresini azaltmak, etkililiği ve performansı artırmak ve kullanıcı memnuniyetini artırmaktır (Shneiderman ve Plaisant, 2003).

Alanyazın incelendiğinde kullanılabilirlikle ilgili farklı değerlendirme yöntemlerinin olduğu görülmektedir. Son dönemde teknolojik gelişmeler ile birlikte ön plana çıkan göz izleme yönteminin yanında, uzman değerlendirmesi, gözlem, anket, sesli düşünme yöntemi, log kayıtları, kâğıt üzerinde ilk örnekleme (kâğıt prototip), canlandırma, ortak keşif, kart sıralama, tekrarlı çalışmalar, katılımcı-tabanlı tasarım, odak grup araştırması, video ve ses kaydı, kullanılabilirlik testleri gibi yöntemlerin de olduğu belirlenmiştir (Budak, 2016; Yeniad, Mazman, Tüzün ve Akbal, 2011).

Kullanılabilirlik çalışmaları konusunda birçok farklı yöntem ve teknik olsa da, daha hızlı dönüt almak ve iyileştirmeler yapılabilmesi, maliyetinin ve harcanan zamanın düşük olması gibi yararları, kullanılabilirlik konusunda kâğıt prototiplerle çalışılmasını beraberinde getirmektedir. Bu anlamda kâğıt prototipler üzerinde verilen görevlerin değerlendirilmesi, kullanıcı merkezli tasarımlarda önemli bir yere sahiptir. Böylece kullanıcılar ilk sayfadan son sayfaya kadar ulaşacakları nihai hedef olan bütün sayfaları görebilmektedir. Dolayısıyla tasarım sürecinin başında bu tür prototiplerin hızlıca üretilmesi, kullanıcı deneyimlerinin göz önünde bulundurularak bir sistemde değiştirilmesi gereken yerlerin hızlı ve ucuz bir şekilde öğrenilmesini beraberinde getirebilir. (Boling ve Frick, 2002; Rubin ve Chisnell, 2008). Nitekim alanyazında da web sayfası geliştirirken kâğıt prototip yapmanın araştırmacılara;

- Kâğıt üzerinde bir web sayfası şemasının çizilmesinin herkesin içeriği daha rahat görebileceğini ve tasarım problemlerini daha rahat teşhis edebileceği,

- Bilgisayar becerisi düşük kullanıcılar için ilk testlerde kâğıt prototip kullanmanın endişeleri azaltabileceği,

- Kâğıt prototiplerin bilgisayara ihtiyaç duymadan her yerde kullanılabileceği,

- Kâğıt prototipler, taslak olarak görüldüğü için değiştirilebileceğine inanma olasılığının daha yüksek olabileceği,

- Test sırasında kâğıt prototipler üzerinde doğrudan düzeltme yapılabileceği,

gibi katkılar getirdiği ifade edilmektedir (Boling ve Frick, 2002). Kâğıt prototip ile ilgili alanyazında yapılan çalışmalar kronolojik olarak aşağıda verilmiştir.

Rante, Schelhowe ve Lund (2016), yaptıkları çalışmada, Endonezya'dan kültürel miraslardan biri olan batik yapma sürecini anlamada çocukları desteklemek için geliştirilen oyun tabanlı bir öğrenme ortamı olan BatiKids'i tasarlama aşamasında kâğıt prototip kullanmışlardır. Araştırma sonucuna göre geliştirme aşamasında kâğıt prototiplemenin zamandan ve materyalden tasarrufun yanısıra tasarımcıya pratik kullanıcı geri bildirimi sağladığı, iletişimi kolaylaştırdığı, yaratıcılığı artırdığı, kullanılabilirliği arttırdığı ve çok fazla teknik beceri gerektirmediği ifade edilmiştir.

Tao ve Or, (2012), yeni kronik hastalıklarla ilgili yönetim sisteminin kullanılabilirliğini arttırmak için yaptıkları çalışmada kâğıt prototip kullanılabilirlik değerlendirmesi yapmışlardır. Sistemin kullanılabilirliğini değerlendirmek için görevin tamamlanma oranı, görevin tamamlanma süresi, hata sıklığı, yardım sıklığı, memnuniyet, algılanan yarar ve algılanan kullanım kolaylığı gibi ölçütler ele alınmıştır. Araştırma sonucuna göre sistem navigasyonu, bilgi arama ve yorumlama, bilgi sunumu ve okunabilirlik ile ilgili çeşitli kullanılabilirlik problemlerinin belirlendiği ifade edilmiştir. Sonuç olarak kâğıt prototip çalışmasının, sistemin tasarım zayıfıklarını tespit etmede ve tasarımı iyileştirmek için uygun öneriler sunmada kolaylık sağladığı ifade edilmiştir. 
Walker, Takayama ve Landay (2012), kâğıt prototip ile bilgisayar prototiplerini karşılaştırdıkları çalışmada aralarında anlamlı bir fark ortaya çıkmadığından dolayı kâğıt prototip kullanma fikrini desteklediklerini ifade etmişlerdir. Özellikle kâğıt prototiplerin maliyet ve iyileştirebilme avantajlarından dolayı bu fikrin ön plana çıktığı belirtilmiştir.

Yukarıda verilen çalışmalar irdelendiğinde kâğıt prototiplerin, sistem tasarımının ilk aşamasında işlevsel bir rol oynadıkları ifade edilebilir. Tasarımcıların ve gerçek kullanıcıların kâğıt prototipler aracılığıyla tasarım sürecinin ilk aşamasında bir araya gelerek, kullanıcı hataları ve yorumlarıyla, kullanım sorunlarını veya tasarım hatalarını daha rahat bir şekilde bulabileceği ileri sürülebilir. Buradan hareketle, bu çalışmada, tasarım ve geliştirme süreci devam eden bir EPDS'nin kullanılabilirlikle ilgili ilk döngüsünün süreç ve sonuçları paylaşılmıştır. Tasarım geliştirme aşamasının birinci döngüsünde ilk tasarımı yapılan EPDS'nin kâğıt prototip kullanılabilirliği incelenerek sistemde değiştirilmesi gereken veya sorunların olduğu yerler belirlenmeye çalışılmıştır. Böylece gerçek sistem geliştirilirken ortaya çıkabilecek sorunlar en aza indirgenmeye çalışılarak, kullanılabilirlikle ilgili ikinci döngünün temelinin oluşturulması amaçlanmıştır.

Bu çalışmada erken çocukluk özel eğitiminde erken müdahaleyi desteklemek amacıyla 0-6 yaş arası çocukların gelişimlerini izleyip raporlamaya ve öğretmenlerin veya uygulayıcıların performanslarını desteklemeye yönelik bir EPDS’ nin kâğıt prototipinin kullanılabilirliği incelenmiştir.

Bu amacı gerçekleştirmek için aşağıdaki sorulara yanıt aranmıştır;

1. 0-6 yaş arası çocukların gelişimlerinin izlenmesi ve raporlaması sürecinde kullanıcıların ihtiyaçları ve beklentileri nelerdir?

2. Kâğıt prototipin kullanılabilirlik değerlendirmesi nasıldır?

a. Katılımcıların kağıt prototip üzerinde verilen görevleri tamamlama durumları nedir?

b. Katılımcıların kağıt prototip üzerinde görevlerde yaşadıkları sorunlar nelerdir?

\section{YÖNTEM}

Kâğıt prototip tasarlanması ve kullanılabilirliği çalışmasında, ADDIE öğretim tasarım modeli referans alınarak aşağıdaki işlem basamakları izlenmiştir (Şekil 1).

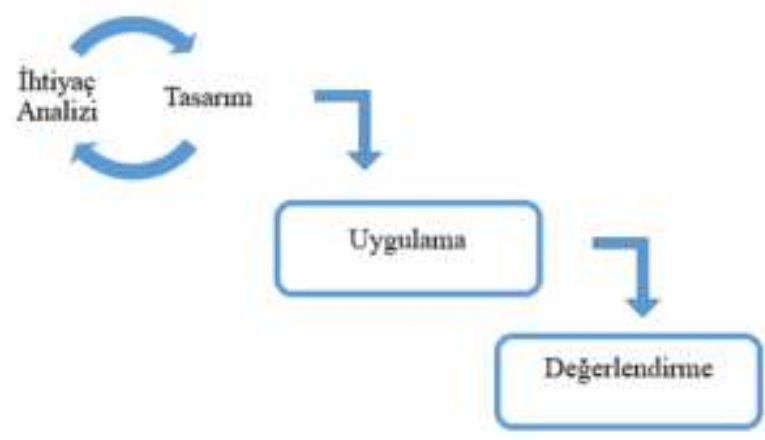

\section{Şekil 1. Yöntem işlem basamakları}

İlk aşamada ihtiyaç analizi ve tasarım süreci birlikte ele alınmıştır. Sistemi kullanacak kişilere ulaşılarak ihtiyaçları, beklentileri ve becerileri belirlenmeye çalışımıştır. Bu aşamada yarı yapılandırılmış görüşmeler yapılarak kâğıt prototip hazırlanmıştır. İkinci aşama olan uygulama aşamasında bu kâğıt prototipin kullanılabilirlik değerlendirmesi yapılmıştır. Son aşamada ise elde edilen veriler analiz edilerek değerlendirilmiş ve sistemde yapılacak iyileştirmelere yönelik öneriler sunulmuştur.

\section{Ihtiyaç Analizi ve Tasarım}

Bu aşamada öncelikle bir özel eğitim kurumunda yönetici ve uzman olan bir katılımcı ile yapılan yapılandırılmamış görüşmeler neticesinde sistemin ilk kâğıt prototip taslağı oluşturulmuştur. Daha sonra bu kâğıt prototip taslağının geliştirme sürecinde üç farklı özel eğitim ve rehabilitasyon merkezinde özel eğitim alanında çalışan toplam sekiz öğretmen, yönetici ve uzman ile ihtiyaç analizi yapılmıştır (Tablo 2). 
Tablo 2. İhtiyaç analizi sürecinin katılımcıları

\begin{tabular}{lccccc}
\hline Cinsiyet & Yaş & Üniversite & Bölüm & $\begin{array}{c}\text { Deneyim } \\
\text { (Yıl) }\end{array}$ & Görev \\
\hline K & 41 & Hacettepe & Çocuk Gelişimi & 13 & Yönetici-Öğretmen \\
K & 35 & Hacettepe & Rehberlik ve Psikolojik Danışmanlık & 12 & Öğretmen \\
K & 34 & Gazi & Sını Öğretmenliği & 9 & Ögetmen \\
K & - & Gazi & Özel Eğitim & 16 & Yönetici-Uzman \\
K & 48 & Anadolu & Okul öncesi Öğretmenliği & 17 & Uzman Öğretmen \\
K & 41 & Anadolu & Okul öncesi Öğretmenliği & 10 & Özel eğitim alan öğretmeni \\
K & 47 & Anadolu & Okul öncesi Öğretmenliği & 17 & Uzman eğitici öğretmen \\
K & 26 & Cumhuriyet & Okul öncesi Öğretmenliği & 1 & Uzman Öğretmen \\
\hline
\end{tabular}

ìhtiyaç analizinde, öğretmenlerin, yöneticilerin, uzmanların, günlük ve mesleki hayatta kullandıkları teknolojiler, çocukların gelişim izleme raporlama sürecini nasıl yürüttükleri ve taslak sistem hakkındaki önerileri ile ilgili görüşmeler yapılmıştır. Üç farklı kurumda yapılan görüşmelerde katılımcıların hepsinin kadın olması tamamen tesadüftür. Özel eğitim alanında çalışan öğretmenlerin farklı bölümlerden mezun olmalarına rağmen özel eğitim alanında çalışmaları dikkati çekmektedir. Bu öğretmenlerin genellikle sertifika programı ve aldıkları özel kurslar ile özel eğitim kurumlarında öğretmen oldukları belirlenmiştir.

Yarı yapılandırılmış görüşmeler neticesinde sistemin web tabanlı mobil uyumlu bir sistem olmasının kullanıcılar için uygun olacağı ortaya çıkmıştır. İhtiyaç analizi çerçevesinde sekiz kişi ile yapılan görüşmeler neticesinde sistemin kâğıt prototip taslağına son şekli verilmiş ve kelime işlemci programında bir sistem taslağı oluşturularak kâğıt çıktısı alınmıştır (Şekil 2).

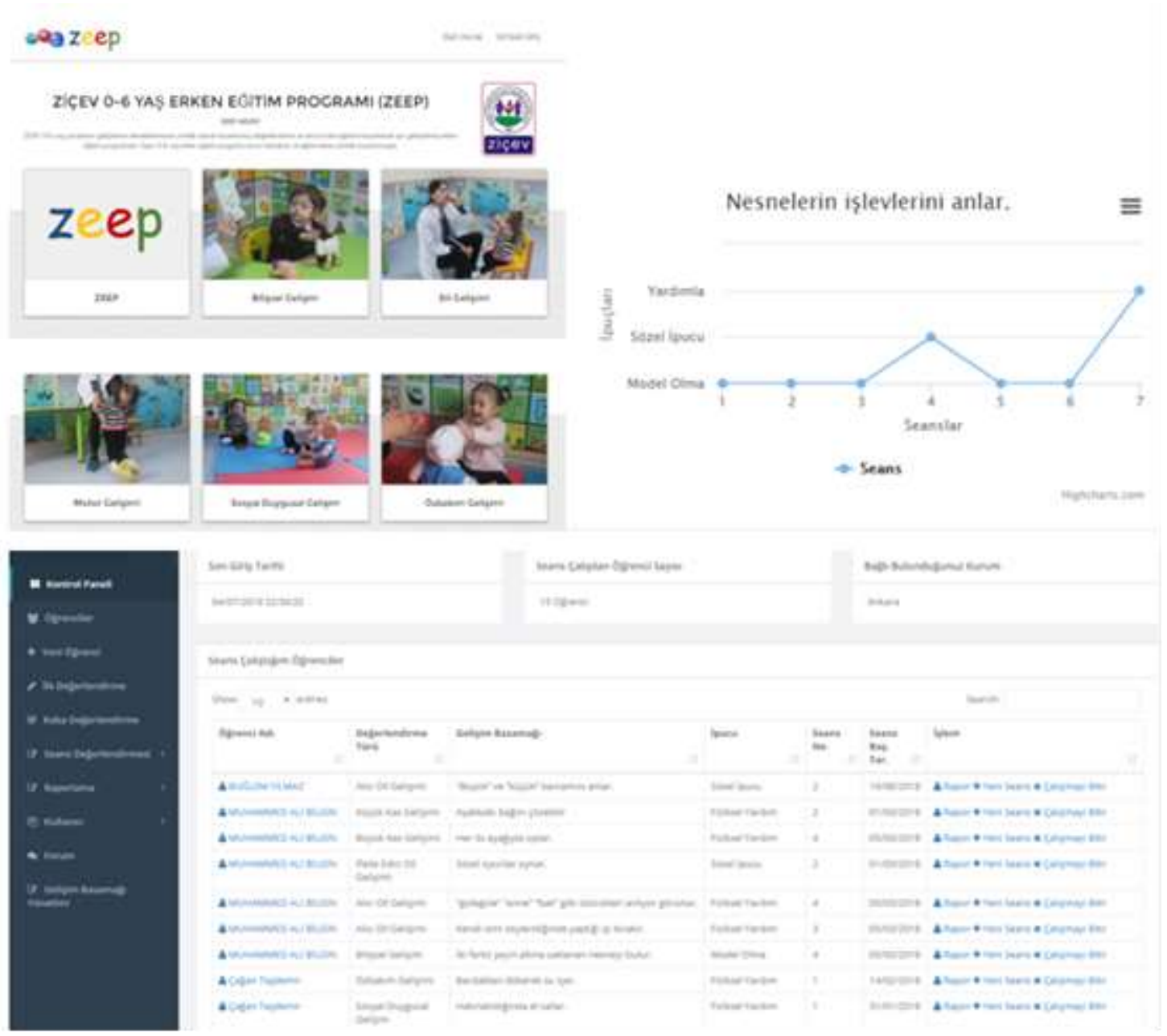

\section{Şekil 2. Kâğıt prototip örnek sayfalar}

Toplam 12 sayfadan oluşan ve her sayfanın üst kısmında hangi işlemin yapılacağına dair bir başlığın yazılı olduğu taslak hazırlanmıştır. Bu sayfalar;

1. Sistemin ana sayfası: Sistemin web adresi girildiğinde hem sistem hem de gelişim alanları ile ilgili bilgilendirmelerin olduğu ana sayfadır. EPDS'nin bileşenleri olan veritabanı ve arayüz bu sistemde giriş sayfasından itibaren bütün sayfalarda bulunmaktadır.

2. Hesap oluşturma sayfası: Sisteme üye olmayan kullanıcı ana sayfadaki üye ol butonuna tıkladığında karşısına gelecek üyelik sayfası.

3. Sisteme giriş sayfası: Sisteme daha önceden üye olan kullanıcıların kullanıcı adı ve şifresini girecekleri sayfa. 
4. Kullanıcı adını girdikten sonra gelen sayfa: Kullanıcı adı ve şifre girdikten sonra sistemin gelişim izleme ve raporlama ile ilgili elektronik performans destek sistemine geçtiği ilk sayfa. Ayrıca bir EPDS'de olan öğretimsel sistem bileşeni bu sayfada yer alacaktır. Kullanıcı sisteme ilk giriş yaptığında, sistemin nasıl kullanıldığını anlatan bir öğretim aracı devreye girecektir. Ek olarak kullanıcının istediği zaman bu aracı çalıştırabileceği buton da en üstte yer almaktadır.

5. Öğrencilerin listelendiği sayfa: Gelişimlerin izlenmesi ve raporlanması için sisteme eklenen öğrenci veya çocukların listelendiği sayfa. Bu sayfada, eklenen kişinin engel türü, doğum tarihi görülecektir. Ayrıca eklediği öğrenciyi silme veya düzenleme yapmaya izin verilecektir.

6. Yeni öğrenci ekleme sayfası: Yeni öğrencinin veya çocuğun ekleneceği sayfa.

7. Ilk değerlendirme sayfası: Sisteme eklenen öğrenci veya çocuğun ilk değerlendirme verilerinin girildiği sayfa.

8. Kaba değerlendirme sayfası: Sisteme eklenen öğrenci veya çocuğun öğretmen tarafından kaba değerlendirmesi ile ilgili verilerinin girildiği sayfa.

9. Seans değerlendirme sayfası: EPDS sisteminde kullanıcıların her an yardım alabileceği uzman/danışman bileşeninin olduğu sayfa burasıdır. Her bir değerlendirmenin nasıl yapılacağının hem yazılı hem de video şeklinde olduğu ve değerlendirmelerde kullanılacak yardımcı araçların neler olduğunun gösterildiği sayfadır.

10. Mesaj sayfası: Kullanıcıların kendi aralarında mesajlaşabileceği sayfa.

11. Genel rapor sayfası: EPDS'de kullanıcıların öğrenci veya çocukların gelişimleriyle ilgili daha önce yaptıkları ve devam eden seansların dökümünü rapor şeklinde alabilecekleri sayfa.

12. Grafik rapor sayfası: EPDS'de kullanıcıların öğrenci veya çocukların gelişimleriyle ilgili daha önce yaptıkları ve devam eden seansların dökümünü görsel olarak grafik raporu şeklinde alabilecekleri sayfa.

\section{Uygulama}

Özel eğitime ihtiyaç duyan 0-6 yaş arası çocukların gelişimlerinin izlenip raporlanmasını için tasarlanan sistemin kâğıt prototipi hazırlanmıştır. Kullanılabilirlik testi için katılımcılardan aşağıda belirtilen 10 tane otantik görevi yapmaları istenmiştir:

1. Sisteme üye olunuz.

2. Sisteme bir öğrenci ekleyiniz.

3. Öğrencinin ilk değerlendirmesini yapınız

4. Sisteme ilk kayıt yaptığınız öğrencinin kaba değerlendirmesini yapınız.

5. Sistemde kayıtı̈ı̆ğrencilerinizden Mehmet Yıldız'ı adına göre arayıp bulunuz

6. Mehmet yıldız adlı öğrencinin Bilişsel gelişim alanı ile ilgili değerlendirmesini yapınız

7. Mehmet yıldız adlı öğrencinin raporunu çıktı olarak alınız

8. Mehmet yıldız adlı öğrencinin bilişsel gelişim alanı 3-6 ay becerilerinden olan "küçük olan nesnelere bakar" becerisinin grafik değerlendirmesinin çıktısını alınız.

9. Okul yöneticisine bu ayki raporların tamamlandığına dair mesaj gönderiniz.

10. Sistemden çıkış yapınız.

Test süreci başlamadan önce katılımcıya kâğıt prototip ve sistem tanıtılmış daha sonra test süreci hakkında bilgi verilmiştir. Teste başlamadan önce katılımcı sistemi tanımak için kâğıt prototip üzerinde inceleme yapmıştır. Daha sonra kullanıcıya gerçekleştirmesi gereken görevler verilmiştir. Bu görevleri gerçekleştirirken katılımcının sesli düşünmesi istenmiştir. Aynı zamanda süreçte katılımcıdan ya parmağıyla ya da uygun olan herhangi bir obje ile menüler ve sayfalar arasında gezinmesi, arama yapacağı ya da metin kutularına girmek istediği bilgileri sesli olarak dile getirmesi istenmiştir. Süreçte katılımcı takıldığı noktalarda araştırmacıya soru sormuş ve sıkıntı olan noktalarda görevi baştan yapmıştır. Bu süreç katılımcının izni ile kamera ve not tutularak kayıt altına alınmıştır. Teste başlamadan önce katılımcının demografik bilgileri kayıt edilmiştir. Test bittikten sonra katılımcıların önerileri alınmıştır.

Kullanılabilirlik çalışması, bir özel eğitim kurumunda görevleri farklı olan beş katılımcı ve farklı bir kurumda görev yapan uzman tasarımcısı bir kişi ile yürütülmüştür (Tablo 3). Nielsen (2000) kullanılabilirlik çalışmalarında katılımcı sayısının beş olduğu durumlarda kullanılabilirlik sorunlarının \%85'inin tespitinin mümkün olduğunu belirtmiştir (Şekil 3).

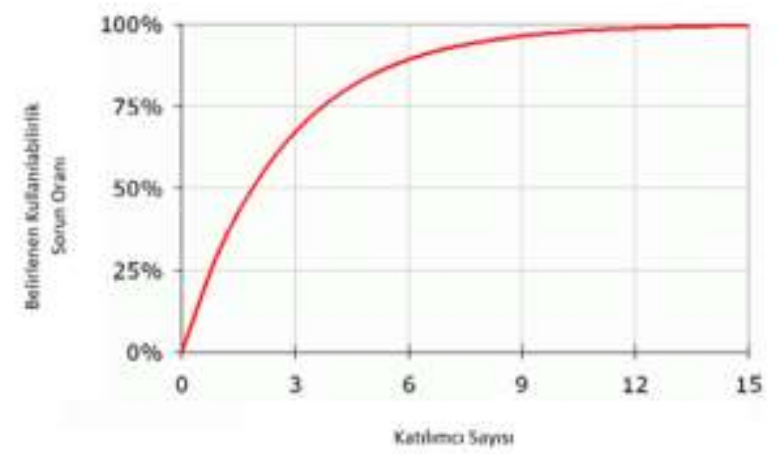

Şekil 3. Nielsen'in kullanılabilirlik için kullanıcı sayısı grafiği 
Kullanılabilirlik testlerinin amaçlarından bir tanesi de doğal ortamda gerçek kullanıcı ile onu izleyen ve değerlendiren bir gözlemcinin olmasıdır (Norman ve Panizzi, 2005). Bu çalışmada da özel eğitim kurumunda çalışan otantik kullanıcılar tercih edilmiştir. Bunun yanı sıra farklı uzman tasarımcılar ile çalışılarak sistemde olası sorunların da ortaya çıkarılması hedeflenmiştir. Çalışma grubunda yer alan altı katılımcının demografik verileri Tablo 3'de yer almaktadır. Katılımcıların çoğunun özel eğitim alanıyla ile ilgili uzman eğitimci sertifikası alan öğretmenlerden oluştuğu görülmektedir.

Tablo 3. Kullanılabilirlik çalışmasına katılanlar

\begin{tabular}{lccc}
\hline Katılımcı & Kurumdaki Görevi & Cinsiyet & Çalışma Süresi (Yıl) \\
\hline K1 & Uzman Tasarımcı & Erkek & 8 \\
K2 & Fizyoterapist & Erkek & 3 \\
K3 & Uzman Öğretici & Kadın & 8 \\
K4 & Uzman Öğretici & Kadın & 18 \\
K5 & Uzman Öğretici & Kadın & 21 \\
K6 & Yönetici-Uzman-Eğitim Koordinatörü & Kadın & 18 \\
\hline
\end{tabular}

\section{Değerlendirme}

Bu çalışmada veriler; ihtiyaç analizi için dört bölümden (demografik, teknoloji kullanımı, gelişim izleme ve raporlama, taslak sistem ile ilgili görüşler) ve 27 sorudan oluşan yarı yapılandırılmış bir görüşme formu ile toplanmıştır. Kapsam ve görünüş geçerliği için dört uzmanın görüşüne başvurulmuştur. Bu görüşler doğrultusunda bazı sorularda değişiklikler yapılmıştır. İhtiyaç analizi verileri MAXQDA nitel veri analiz programı ile çözümlenmiştir. Bu bağlamda ihtiyaç analizi görüşme formunun dört temel soru başlığı tema olarak ele alınmış ve onun altında kodlar ve kategoriler oluşturulmuştur.

Kullanılabilirlik ile ilgili veriler video ve ses kayıtları ile toplanmıştır. Buna ek olarak süreçte dört basılı form kullanılmıştır. illk olarak katılımcıya bu çalışmaya gönüllü olarak katıldığını belgeleyen bir form verilmiştir. İkinci formda katılımcının demografik verileri; üçüncü formda bu çalışma kapsamında yapacağı görevlere yer verilmiştir. Son olarak araştırmacının çalışma sırasında katılımcının izlediği yolları, davranışları vb. notlarını tutacağı gözlemci formu kullanılmıştır. Görevleri tamamladıktan sonra katılımcılara önerileri ve bu sistemi gelecekte kullanma niyetleri sorulmuştur. Veriler toplanırken çalışma süreci hem kamera hem de ses kaydı ile takip edilmiştir.

Kullanılabilirlik çalışmasından elde edilen verilerin analiz edilmesinde sırasıyla aşağıdaki adımlar izlenmiştir (Çıralı, Özgür, Olgun ve Tüzün, 2012).

1. Bir görevi tamamlamak için olası izlenecek yol adımları belirlenmiştir.

2. Her bir katılımcının her görev için hangi adımları takip ettiği video kayıtları ve ses kayıtları incelenmiş ve betimlenmiştir.

3. Katılımcıların görevi tamamlama durumları ayrı bir tabloda özetlenmiştir.

4. Son olarak süreçte görev tamamlama durumuna göre sistemde yapılacak değişimler için öneriler sunulmuştur.

\section{BULGULAR}

\section{Kullanıcıların, ihtiyaçları ve beklentileri nasıldır?}

İhtiyaç analizi sürecinde öğretmen ve uzmanlarla yapılan görüşmelerden elde edilen verilerin analizi sonucunda, teknoloji, öğrenci/çocuk gelişim izleme ve raporlama süreçleri, taslak sistem hakkındaki görüşler, taslak sistem hakkındaki öneriler olmak üzere dört tema ortaya çıkmıştır. Bu dört ana tema ve bu temaların altında oluşan kategoriler ve kodlar tablo 4'te sunulmuştur. Teknoloji teması altında; günlük yaşamda kullanılan teknolojiler, mesleki yaşamda kullanılan teknolojiler, teknoloji kullanımı sürecinde güçlük çekilen noktalar, özel eğitimde teknoloji kullanımına ilişkin görüşler olmak üzere dört farklı kategori oluşmuştur. Bu dört kategori altında da kodlar oluşmuştur. Öğrenci/çocuk gelişim izleme ve raporlama süreçleri teması altında; izleme süreci ve raporlama süreci olmak üzere iki kategori oluşmuştur. Bu kategoriler altındaki kodlar tablo 4'te verilmiştir. Taslak sistem hakkındaki görüşler teması altında; sistemin yararları, sistemi beğenme, sistemde yaşanabilecek problemler, veli olmak üzere beş kategori oluşmuştur. Bu kategori altındaki kodlar tablo 4'te verilmiştir. Taslak sistem hakkındaki öneriler teması altında; raporlama ile ilgili öneriler, seans, ilk ve kaba değerlendirme hakkında öneriler, öğrenci kayıtlarıyla ilgili öneriler, EPDS bileşenleri ve diğer öneriler olmak üzere beş kategori oluşmuştur. Yine bu kategoriler altındaki kodlar tablo 4’te verilmiştir. 
Tablo 4. İhtiyaç analizi ile ilgili temalar, kategoriler ve kodlar

\section{Teknoloji}

a) Günlük yaşamda kullanılan teknolojiler

- Cep Telefonu

- Bilgisayar

- Tablet

- Sosyal Medya

- Internet

b) Mesleki yaşamda kullanılan teknolojiler

- Cep telefonu

- Oyuncak, Eşleme, Yapboz vb. araçlar

- Bilgisayar

- Internet

- Video

c) Teknoloji kullanımı sürecinde güçlük çekilen noktalar

- Arkadaş yardımıyla

- Deneme yanılma yoluyla

- Teknolojiden uzak yaşam

d) Özel eğitimde teknoloji kullanımına ilişkin görüşler

- Teknoloji kullanımına ilişkin olumlu görüşler

- Teknoloji kullanımının dezavantajı

3. Taslak sistem hakkındaki görüşler

a) Sistemin yararları

- Gelişimleri düzenli izleme

- Zaman Tasarrufu

- Süreklilik

- Veri arşivlemeyi kolaylaştırma

- Raporlamayı kolaylaştırma

b) Sistemi beğenme nedenleri

- Kullanımı kolay

- Sistemi kullanma istekleri

- Sistemin kolaylaştırıcı rolü

c) Sistemde yaşanabilecek problemler

- Internet problemi

- Teori-uygulama farkı

d) Veli

- Velinin çocuğunu değerlendirmesi

- Velinin öğretmene bakış açısı
2. Öğrenci/çocuk gelişim izleme ve raporlama süreçleri

a) İzleme Süreci

- YOPECK Programı kullanarak

- Rehberlik Araştırma Merkezi (RAM) raporuna uygun giderek

- Bilgisayar kullanarak

- Kâğıt kalem ile not alarak

- Kendi geliştirdiği yöntemler ile

- Gözlem yoluyla

b) Raporlama Süreci

- Kâğıt kalem ile raporlama

- Bilgisayar üzerinden raporlama

- YOPECK programı üzerinden raporlama

- Velilere raporları sunma

- Raporlamada yaşanan sıkıntılar

Tablo 4'te verilen her tema, ilgili öğretmen/uzman ifadelerinden yapılan alıntılarla desteklenerek aşağıda açıklanmıştır.

\section{Teknoloji:}

Tablo 4 incelendiğinde katılımcıların günlük ve mesleki yaşamda cep telefonu ve bilgisayarı sıklıkla kullandıkları belirlenmiştir. Mesleki anlamda teknoloji kullanımı incelendiğinde katılımcıların cep telefonu, bilgisayar, internet, video gibi teknolojileri genellikle sınıf içi etkinliklerde kullandıkları belirlenmiştir. Katılımcıların mesleki yaşamda en çok kullandığı teknolojiler arasında cep telefonu yer almaktadır. Bir katılımcı şöyle ifade etmiştir:

“... Google Play'den indirdim. Şu hayvan sesleri işitsel girdiyi bu şekilde telefondan yapıyorum zaten görsel bilgi kartlarla inek inekti şeklinde" $\mathrm{K} 1$

Mesleki anlamda teknoloji kullanımı incelendiğinde katılımcıların bu teknolojileri genellikle sınıf içi etkinlikleri destekleyecek ya da öğrettiklerini pekiştirme amacıyla kullandıkları dikkati çekmektedir. Katılımcılardan birisinin aşağıda yer verilen ifadesi bu bulguyu desteklemektedir.

“Kavram öğretimi sayı öğretimi, tane, diyelim ki elimizdeki malzemeyle kullandığım o kart ya da diğer materyallerle göstermişim ama bilgisayardan da yine o kavramları destekliyorum. ..." $\mathrm{K} 2$

Bunların yanı sıra oyuncak, eşleme ve yapbozlar da katılımcıların kullandıkları başka araçlar olarak dikkati çekmektedir. Genellikle bu tür araçların kavram öğretiminde, çocukların üç boyutlu olarak kavramları görebilmesi ve öğrendiklerini pekiştirmek amaçıı kullanıldığı belirlenmiştir. Bir katılımcı bu araçları nasıl kullandığını aşağıdaki gibi ifade etmiştir:

"Şimdi ben hayvanları çalıştım diyelim ki oyuncaklarım var sınıfta eşleme yapıyorum artı hayvanları hem görsel hem de işitsel olarak dinletiyorum. Bu şekilde görsel üç boyutlu ve sesli olarak pekiştirme çalışıorum." K1 


\section{Öğrenci/çocuk gelişim izleme ve raporlama süreçleri:}

Öğrencilerin gelişim izleme ve raporlama süreçleri ile ilgili öğretmenlerin görüşleri incelendiğinde bu süreçte daha çok kâğıtkalem kullandıkları, ayrıca bilgisayar üzerinden hesaplama ya da kelime işlemci gibi programları da kullandıkları belirlenmiştir. Ek olarak, YOPECK adlı bilgisayar tabanlı program ile RAM (Rehberlik Araştırma Merkezi) raporları doğrultusunda bu süreci yürüttükleri belirlenmiştir. Bazı katılımcılar süreçte yaptıklarını şöyle ifade etmiştir:

"Uyguladığım basit test renkleri biliyor mu? Şekilleri biliyor mu? Harfleri rakamları. A4 boyutunda bir test artı eksi yapıyorum." K3

Katılımcıların izleme ve raporlama sürecinde daha çok çocuğun gelişimi ile ilgili veliye rapor sunmada bu süreci kayıt altına aldıkları belirlenmiştir.

"Deftere not alıyorum veliye diyorum ki bunları bunları yaptım bunları yapabildi bunları yapamadı sizde evde şunları çalışın diye o defteri gönderiyorum." $\mathrm{K} 2$

\section{Taslak sistem hakkındaki görüşler:}

Geliştirilen taslak prototip ile ilgili görüşlerden elde edilen veriler incelendiğinde katılımcıların birçoğu sistemi beğendiğini, sistemin gelişim izleme ve raporlamada yarar sağlayacağını, zaman kaybının önüne geçeceğini belirtmiştir. Genel olarak sistemin kolay ve kullanılabilir olacağı, verilerin düzenli bir şekilde saklanmasının gelişim izleme ve raporlamada bir süreklilik sağlayacağı ifade edilmiştir.

"Sürekliliği olur eğitim açısından çocuğun zaman kaybı olmaz." K4

Katılımcıların ifadeleri incelendiğinde böyle bir sistemin öğretmenlere ve öğrencilere sağladığı katkıların yanı sıra velilere yönelik yararlarının olacağı da dile getirilmiştir. Katılımcıların ifadelerine bakıldığında EPDS'nin, hem velilerin çocuklarının gelişimlerini takip etmede, hem de veli-öğretmen iletişimini güçlendirmede katkı getireceği ileri sürülebilir. Ayrıca böyle bir sistem sayesinde velinin kendi çocuğuna eğitim veren öğretmeni değerlendirmede kolaylık sağlayacağı katılımcılar tarafından ifade edilmiştir.

“Hem veli gözleriyle hem de derki bu öğretmen gerçekten benim öğrencimle ilgileniyor. Neler hazırlamış çok güzel şeyler hazırlamış. Memnun kalır diye düşünüyorum. Ben veli olsam benim çocuğumla ne kadar ilgilendiklerini gösteren konulara çok memnun olurum. Aynı şekilde bizim velilerimizin de öyle olacağını umuyorum." K5

\section{Taslak sistem hakkındaki öneriler:}

Taslak prototip ile ilgili katılımcılardan elde edilen veriler incelendiğinde küçük güncelleme ve düzeltmelerin yanı sıra EPDS'nin temel bileşenleri arasında olan danışman sistem bileşeni ve sistemin kullanımı ile ilgili bir öğretimsel sistem bileşenine ihtiyaç olduğu belirlenmiştir. Özellikle alanda çalışmaya yeni başlamış öğretmenler için danışman sistem bileşeninin ve teknoloji kullanımı konusunda düşük beceriye sahip öğretmenlere de öğretimsel sistem bileşeninin yararlı olabileceği ifade edilebilir. Nitekim göreve henüz yeni başlamış bir katılımcı kendi geliştirdiği yöntemde bir süre sonra zorlandığını şöyle ifade etmiştir.

“Cep telefonuyla sınıfta video çekiyorum sonra izliyorum onları tamamen kendim için yaptığımız etkinliklerin fotoğraf çekiyorum... Özel eğitimci olmadığım için bazen bunların videolarını yakın arkadaşlarıma alandaki arkadaşlarımla paylaşıyorum yaptıklarım doğru mu diye onlardan çok bilgi alışverişi yapıyorum." K3

Öğretmenin ifadesi incelendiğinde özellikle öğrencilerin becerilerinin değerlendirilirken yaşadığı zorluk ve bu konuda uzmanlardan destek almaya ihtiyaç duyduğu belirlenmiştir. Bu anlamda danışman sistem bileşeninde öğretmenlerin beceri değerlendirme sürecini destekleyecek değişikliklerin yapılmasının uygun olduğu düşünülmektedir. Herhangi bir beceriyi değerlendirirken öğretmeni destekleyecek video veya yazıların olması bu konuda yeni başlamış veya farklı branşlardan gelmiş öğretmelerin yaşadığı problemleri azaltabilir. Daha önceden uzman veya tecrübeli kişilerin hazırladığı videolar sisteme eklenerek bir becerinin nasıl değerlendirileceği ile ilgili örnek bir olay gösterilebilir. Böylece öğretmenler beceri değerlendirmeden önce bu video veya yazılara bakarak nasıl değerlendirme yapması gerektiği konusunda fikir sahibi olabilir.

Kurumda yönetici olarak görev yapan bir katılımcı, kurumunda görev yapan öğretmenlerin teknoloji kullanımı ile ilgili zorluklar yaşadığını ve sistem kullanım ile ilgili yönergeler olması gerektiğini ifade etmiştir. EPDS’nin bir diğer bileşeni olan öğretimsel sistem bileşeni ile ilgili geliştirilecek EPDS'nin her bir bileşenin nasıl kullanabileceği konusunda hazırlanacak kısa videolar ile teknoloji kullanımı konusunda yetersiz olan öğretmenlere destek sağlanabilir.

Öğretmenlerin bu sistemin üst yaş gruplarının becerilerini kapsayacak şekilde güncellenmesine yönelik önerilerinin yanı sıra MEB ile bağlantı kurulmasına yönelik önerilerinin de olduğu dikkati çekmektedir. Bu anlamda MEB ile bağlantı kurularak böyle bir sistemin denemesi yapılabilir. Sisteme öğrencileri eklemek yerine bu bilgiler MEB'den sisteme otomatik olarak alınabilir. Böylece öğrencinin hangi gelişim alanları üzerinde çalışma yapılacağı ile ilgili RAM raporları sistem üzerinden ilgili öğretmene aktarılarak hem öğrencinin devam ettiği resmi okul hem de özel eğitim ve rehabilitasyon merkezi arasındaki iletişim sürecine de katkı sağlanmış olur. Ancak bunun izin ve uygulama süreci daha çok yönetsel ve bürokratik boyutla ilgili olduğu için bu konu başka bir çalışmada ele alınabilir. Raporlama ile ilgili öneriler kısmında da velilere rapor sunma konusunda sistemde raporların çıktısını alabilecekleri ve bunları velilere e-posta yoluyla iletebilecekleri bir tasarım düşünülmektedir. Rapor uyarı önerisiyle ilgili de çalışması biten beceriler ile ilgili renklendirmeler yapılarak devam eden beceriler yeşil, değerlendirme süreci tamamlanmış beceriler turuncu hiç çalışımamış beceriler ise kırmızı renklerle belirlenip kullanıcıyı bu anlamda bilgilendirecek bir yapının geliştirilmesi planlanmıştır. 
Ulaşılan tema, kategori ve kodlara bütün olarak bakıldığında öğretmenlerin gelişim izleme ve raporlama sürecinde hem performanslarını destekleyecek hem de süreci daha kolay bir hale getirecek bir sisteme ihtiyaç duyduğu görülmektedir. Bu anlamda geliştirilmesi düşünülen sistemde öğretmenlerin evrak işlerinden daha çok öğretimsel sürece odaklanması için gereken bileşenlerin eklenmesinin önemli olduğu ortaya çıkmıştır. Öğretmenlerin görüşleri ve var olan durumları incelendiğinde sistemin kullanımının kolay ve kullanılabilir olmasının faydalı olacağı yönünde görüşlerini ifade etmişlerdir. Ayrıca süreçte iletişimi güçlendirecek araçların eklenmesi öğretmenlerin bir diğer beklentisi olarak ortaya çıkmıştır. Bu anlamda sistemin kullanımını kolaylaştıracak, kullanılabilirliğini arttıracak ve iletişim sürecini güçlendirecek bileşenlerin eklenmesi gerekliliği ortaya çıkmıştır.

\section{Kâğıt prototipin kullanılabilirlik değerlendirmesi nasıldır?}

$\mathrm{Bu}$ ana sorunun detaylı olarak cevaplandırılabilmesi için iki alt sorunun yanıtlanmasına ihtiyaç duyulmuştur. Öncelikle katılımcılara verilen 10 farklı görevin tamamlanma durumlarına bakılmıştır. Daha sonra bu görevleri yaparken yaşadıkları sorunlar göz önünde bulundurularak öneriler getirilmiştir.

\section{Katılımcıların görev tamamlama durumları nasıldır?}

Bu çalışmada gelişim izleme ve raporlama sisteminin kâğıt prototipinin kullanılabilirlik çalışması için katılımcılardan 10 farklı görevi gerçekleştirmeleri istenmiştir. Her bir görevin tamamlanması durumu ile ilgili katılımcının izlemesi gereken adımlar bir sonraki bulguda belirtilmiştir. Bu adımlara uygun hareket edip bütün aşamaları tamamlayan kullanıcılar görevi tamamladı olarak kabul edilmiştir. Bunun yanı sıra farklı adımları yapıp tekrar doğru adımları yapan kullanıcılar da görevi tamamladı olarak kabul edilmiştir. Bazı görevlerde katılımcıdan beklenen ad-soyadı arama gibi adımlar kâğıt prototipten kaynaklı bir durum olduğu için bu adımı atlayan kullanıcıların görevleri eksik yaptıkları kabul edilmiştir. Çünkü gerçek bir sistemde katılımcıların ad-soyadı aratmadan görevin diğer adımlarına gitmesi imkansız olacaktır. Bu çalışma altı farklı katılımcı ile yürütülmüştür. Katılımcıların bu görevi tamamlama durumları Tablo 5'de verilmiştir.

Tablo 5. Kullanılabilirlik görev tamamlama durumları

\begin{tabular}{|c|c|c|c|c|c|c|}
\hline & K1 & K2 & K3 & K4 & K5 & K6 \\
\hline Görev 1 & + & + & - & + & + & + \\
\hline Görev 2 & + & + & + & + & + & + \\
\hline Görev 3 & + & + & + & + & + & Eksik \\
\hline Görev 4 & Eksik & Eksik & Eksik & Eksik & Eksik & Eksik \\
\hline Görev 5 & + & - & - & - & + & - \\
\hline Görev 6 & Eksik & Eksik & - & Eksik & + & Eksik \\
\hline Görev 7 & + & Eksik & Eksik & - & + & Eksik \\
\hline Görev 8 & + & + & + & - & Eksik & Eksik \\
\hline Görev 9 & + & + & + & - & + & + \\
\hline Görev 10 & + & + & + & + & + & + \\
\hline
\end{tabular}

Tablo 5'e bakıldığında bütün görevleri tamamlayan yalnızca iki katılımcı (K1 ve K5) olmuştur. Bu iki katılımcının da iki görevi eksik olarak tamamladıkları belirlenmiştir. Tablo 5 incelendiğinde en çok beşinci, altıncı ve yedinci görevlerde katılımcıların görev tamamlamada başarısız oldukları dikkati çekmiştir. Dördüncü görevi bütün katılımcılar eksik tamamlamıştır. ỉkinci ve onuncu görevleri ise bütün katılımcıların tamamladığı görülmektedir. Birinci, üçüncü ve dokuzuncu görevlerde ise birer katılımcının sorun yaşadığı belirlenmiştir. Görev tamamlama tablosu hazırlanırken katılımcıların yaptı̆̆ı adımlar sırasıyla kaydedilmiş ve bazı görevlerin eksik tamamlandığı bazı görevlerde ise kritik adımlar atlandığı için görevi tamamlamadığı varsayılmıştır.

\section{Katılımcıların görevlerde yaşadıkları sorunlar nelerdir?}

Katılımcıların her bir görevde yaşadıkları sorunlar kümelenerek bu sorunlara uygun öneriler görev sırasına göre aşağıda verilmiştir:

Görev 1- Sisteme üye olunuz. Bu görevde kullanıcıdan ana sayfada sağ tarafta bulunan giriş kısmına tıkladıktan sonra üye ol kısmına tıklayıp daha sonra hesap oluştur sayfasından gerekli bilgileri girip hesap oluştur butonuna tıklaması beklenmektedir.

Bulgu: Sadece bir katılımcı görevi tamamlayamamış. Bir katılımcı ise önce farklı bir sayfaya yönelmiş daha sonra doğru adımları izlemiştir.

Öneri: Bu görevde yer alan öğeler için bir problem olmadığına karar verilmiştir.

Görev 2: Sisteme bir öğrenci ekleyiniz. Katılımcıdan yeni öğrenci ekle butonuna tıklayıp yeni öğrenci bilgilerini girdikten sonra ekle butonuna tıklaması beklenmektedir.

Bulgu: Bir katılımcı ana sayfadaki yeni öğrenci ekleme butonuna tıklamadan direk sayfaya gidip formu doldurup eklemiştir. Bir katılımcı ise direk sayfaya yönelmiş fakat düşündükten sonra adımları doğru bir şekilde tamamlamıştır.

Öneri: Bu görevde yer alan öğeler için bir problem olmadığına karar verilmiştir.

Görev 3- Öğrencinin ilk değerlendirmesini yapınız. Bu görev iki farklı yol ile yapılabilir. 
- Katılımcıdan yeni öğrenciyi ekledikten sonra altta çıkan ilk değerlendirme butonuna basıp ilk değerlendirme sayfasına gidip değerlendirmeyi tamamlayıp kaydet butonuna basması bekleniyor.

- Katılımcıdan değerlendirme butonuna tıkladıktan sonra altta açılan menüden ilk değerlendirmeye tıklaması, öğrencinin adı-soyadını aratması ve formu doldurup kaydetmesi beklenmektedir.

Bulgu: Bir katılımcı kaydet butonuna tıklamadı. Bir katılımcı birinci yol ve ikinci yol adımlarını karıştırdı fakat sonra doğru adımlar şeklinde tamamladı. İki katılımcı ise genel değerlendirme butonları ile karışıklık yaşadıktan sonra doğru bir şekilde ilerledi.

Öneri:

1. İlk değerlendirme tamamlandıktan sonra kaydet tuşuna basmak katılımcıları bazıları tarafından hatırlanmamıştır. Bu sorun göz önünde bulundurulduğunda form doldurulurken sistemin otomatik kaydetmesi yaşanabilecek bazı sorunların önüne geçebilir.

2. Illk değerlendirme ile genel değerlendirme altında bulunan gelişim alanlarının butonları arasında karışıklar olabiliyor. İlk değerlendirme butonu oradan farklı bir yere taşınması bu soruna uygun bir çözüm olabilir.

3. Değerlendirmeleri yapılacak öğrencinin adı soyadını yazdıktan sonra ilk değerlendirme gelişim alanlarının gelmesi ad-soyad aratmayı unutma problemine çözüm olabilir.

Görev 4- Sisteme ilk kayıt yaptığınız öğrencinin kaba değerlendirmesini yapınız. Bu görev iki farklı yol ile yapılabilir.

1. Katılımcıdan yeni öğrenciyi ekledikten sonra altta çıkan kaba değerlendirme butonuna basıp kaba değerlendirme sayfasına gidip değerlendirmeyi tamamlayıp kaydet butonuna basması bekleniyor.

2. Katılımcıdan değerlendirme butonuna tıkladıktan sonra altta açılan menüden kaba değerlendirmeye tıklaması, öğrencinin adı-soyadını aratması ve formu doldurup kaydetmesi beklenmektedir.

Bulgu: Bütün katılımcılar ikinci yoldan adımları tamamlamış fakat hepsi de öğrenci adını aratmamıştır. Ayrıca bir katılımcı farklı sayfaya gittikten sonra görevini tamamlamıştır.

Öneri: Illk değerlendirmeye benzer olarak kaba değerlendirme butonuna tıkladıktan sonra öğrenci adı-soyadı arat ekranı geldikten sonra kaba değerlendirme ekranının gelmesi bu probleme çözüm olabileceği düşünülmektedir. Ya da öğrenci kaydını yaptıktan sonra uyarı olarak öğrencinin ilk ve kaba değerlendirmesi için tıklayınız gibi bir uyarı getirilebilir.

Görev 5-Sistemde kayıtı öğrencilerinizden Merve Yüksel'i adına göre arayıp bulunuz. Katılımcıdan öğrenciler butonuna tıklayıp yukarıda ad-soyad arama yerine öğrencinin adını soyadını yazıp araması bekleniyor.

Bulgu: Dört katılımcı öğrenci adını soyadını aramak için genel arama yerini kullandı.

Öneri: Bu problemin çözümü için iki yol düşünülmüştür. İlk olarak genel arama yerini küçültüp sağ tarafa almak. İkinci olarak ise Öğrenci ad-soyad arama yerini daha ön plana çıkaracak bir şekilde tasarlamak.

Görev 6- Mehmet Yıldız adlı öğrencinin Bilişsel gelişim alanı ile ilgili değerlendirmesini yapınız. Katılımcıdan değerlendirme butonuna tıkladıktan sonra bilişsel gelişim butonuna tıklayıp öğrencinin adı soyadı arama yerine adını yazıp değerlendirmesini tamamlayıp kaydet butonuna tıklaması beklenmektedir.

Bulgu: Bu görevde bütün katılımcılar hata yapmıştır. İki katılımcı öğrenci adını aratmamıştır. Bir katılımcı genel arama yerini kullanmıştır. Bir katıımcı değerlendirme sayfasını direk eline alıp adımları uygulamıştır. íki katılımcı ise öğrenciler sayfasından öğrenciye tıklayarak değerlendirmeye gitmeye çalışmıştır.

Öneri: Bu problemin çözümü için iki yol düşünülmüştür. Illk olarak, genel arama yerinin değiştirilmesi öğrenci aramada yaşanan sıkıntıyı giderebilir. İkinci olarak, değerlendirme sayfasını ayrı yapmak yerine öğrenci sayfasından istenilen öğrenciye tıkladıktan sonra öğrencinin kişisel sayfasından ulaşılabilmesini sağlamak öğrenci adının aratılması sıkıntısının önüne geçebilir.

Görev 7- Mehmet Yıldız adlı öğrencinin genel raporunu çıktı olarak alınız. Katılımcıdan rapor butonuna tıkladıktan sonra genel rapor butonuna tıklayıp öğrencinin adı soyadı arama yerine adını yazıp yazdır butonuna tıklaması beklenmektedir.

Bulgu: Üç katılımcı öğrenci adı-soyadını aratmamıştır. Bir katılımcı ise öğrenciler sayfasına girdikten sonra genel aramadan öğrenciyi aratmış ve genel rapora oradan gitmiştir.

Öneri: Benzer şekilde rapor bölümünün de öğrencinin kişisel sayfasından ulaşılması bu soruna bir çözüm olabilir.

Görev 8- Mehmet yıldız adlı öğrencinin bilişsel gelişim alanı 3-6 ay becerilerinden olan "Küçük olan nesnelere bakar" becerisinin grafik raporunun çıktısını alınız. Katılımcıdan rapor butonuna tıklaması sonra grafik butonuna ve grafiği göster butonuna tıklayıp yazdır butonuna tıklaması beklenmektedir.

Bulgu: iki katılımcı grafiği göster butonuna tıklamamıştır. Bir katılımcı öğrenciler sayfasından öğrenciye tıklayarak grafik sayfasına ulaşmıştır.

Öneri: Çizilen taslakta hazır bir grafik basılı olarak geldiği için katılımcılar direk yazdır butonuna tıklamıştır. Bu nedenle burada problem oluşturacak bir sorunun olmadığı düşünülmektedir. Rapor sayfasına öğrencinin kişisel sayfasından ulaşılması ad-soyad aratmadan rapor çıktısı almaya olanak sunabilir.

Görev 9- Yöneticiye bu ayki raporların tamamlandığına dair mesaj gönderiniz. Katılımcıdan üst menüde bulunan mesaj butonuna tıkladıktan sonra yeni mesaj butonuna tıklayıp gerekli formu doldurup gönder butonuna tıklaması beklenmektedir.

Bulgu: Sadece bir katılımcı adım sayısını fazla yapmıştır. 
Öneri: Bu görevde yer alan öğeler için bir problem olmadığına karar verilmiştir.

Görev 10- Sistemden çıkış yapınız. Katılımcıdan sağ üst köşede bulunan çıkış butonuna tıklaması beklenmektedir.

Bulgu: Bütün katılımcılar görevi başarılı bir şekilde tamamlamıştır.

Öneri: Bu görevde yer alan öğeler için bir problem olmadığına karar verilmiştir.

Kâğıt prototip üzerindeki uygulama işlemi bittikten sonra çalışmada yer alan özel eğitim kurumu çalışanlarına böyle bir sistemi gelecekte kullanma durumları sorulmuştur. Katılımcıların hepsi böyle bir sistemi kullanmak istediklerini ve kullanmaktan memnun olacaklarını dile getirmişlerdir. Sadece bir kullanıcı bu tür sistemleri kullanmada zorluk yaşadığını ve bu kâğıtlar üzerinden kendi kendine çalışabileceğini belirtmiştir.

Katılımcılara sistem ile ilgili önerileri sorulduğunda;

- Bir katılımcı çocuklar ile belirli becerileri çalıştıkları için seans değerlendirmesi yaptığından sadece çalıştığı becerilerin listelenmesinin daha kullanışlı olacağını belirtmiştir.

- Bir katılımcı seans verileri kaydedilirken sistemin otomatik tarih vermesi yerine elle seçilebilir bir tarih atamasının uygun olacağını belirtmiştir.

- Kurumdaki görevi yöneticilik olan katılımcı ise sisteme kayıt olan öğretmenlerin kendi onayından sonra bu sistemi kullanmasına imkân verilmesi gerektiğini belirtmiştir.

- Bir katılımcı ise ailelerin sistemde oluşturulan raporları izleyebilmelerine fırsat verilmesi gerektiğini önermiştir.

\section{SONUÇ VE ÖNERILER}

Bu çalışma, erken çocukluk özel eğitiminde erken müdahaleyi desteklemek amacıyla 0-6 yaş arası çocukların gelişimlerini izleyip raporlamaya ve öğretmenlerin veya uygulayıcıların performanslarını desteklemeye yönelik bir EPDS'nin kâğıt prototipinin kullanılabilirliğini incelemek amacıyla gerçekleştirilmiştir. Bu kapsamda öncelikle sekiz kişi ile ihtiyaç analizi yapılmış, ortaya bir kâğıt prototip taslağı konulmuş ve kâğıt prototipin kullanılabilirliği altı kişi ile değerlendirilmiştir.

İhtiyaç analizi kapsamında özel eğitim öğretmenlerinin ve yöneticilerinin görüşleri alınmıştır. Öğretmenlerin hem mesleki hem de özel hayatlarında mobil teknolojileri kullandıkları belirlenmiştir. Mobil teknolojilerin maliyeti, ulaşılabilirliği ve uygunluğu düşünüldüğünde özel gereksinimli çocuklara alternatif çözümler sunduğu ve yardımcı destek aracı olarak kullanıldığı alanyazında da ifade edilmektedir (Cabielles-Hernandez, Perez-Perez, Paule-Ruiz ve FernandezFernandez, 2017; Ismaili ve Ibrahimi, 2017). Öğretmenlerin mobil teknolojiler aracılı̆̆ılla daha çok görsel öğeleri kullandıkları ortaya çıkmıştır. Sınıf içi etkinlikleri desteklemek amaçlı videoların kullanılmasının yanı sıra bazen sınıfta vakit geçirmek için de bu tür teknolojileri kullandıkları sonucuna ulaşılmıştır. Özel eğitim ile ilgili yapılan son çalışmalarda en çok kullanılan teknolojilerin başında videoların geldiği görülmektedir (Brock ve Carter, 2015; Mason vd., 2013).

ihtiyaç analizinden elde edilen bulgular incelendiğinde deneyimsiz veya farklı alanlardan gelmiş öğretmenlerin gelişim izleme ve raporlama sürecinde zorlandığı ve farklı yöntemler uyguladığı belirlenmiştir. Öğretmenlerin, öğrencilerin gelişimlerinin değerlendirilmesi sürecinde ek desteğe ihtiyaç duyduğu öğretmen ifadelerinden ortaya çıkmıştır. Türkiye'de yapılan çalışmalar incelendiğinde özellikle özel eğitim alanında çalışan öğretmenlerin değerlendirme yaparken bilgi eksikliklerinin olduğu alanyazında ifade edilmektedir (Sazak-Pınar, 2006; Sucuoğlu, Bakkaloğlu, Karasu, Demir ve Akalın, 2013). Bu durumun temel nedenlerinden biri Türkiye'de üniversitelerde sınırlı sayıda özel eğitim öğretmenliği bölümünün olması nedeniyle MEB'nın, farklı branşlardaki öğretmenlere sertifika programları kapsamında eğitim vermesi olabilir. Farklı alanlardan gelmiş öğretmenlerin özel eğitim alanının kuramsal temeli konusunda fazla bilgi sahibi olmaması gelişim izleme ve raporlama sürecini zorlaştırabilir. Öğretmenlerin gelişim izleme sürecinde değerlendirme yaparken zorlanmalarının temel nedenlerinden biri de kuram ve uygulama arasındaki bağı kurmak konusunda zorlanmaları olabilir. Nitekim öğretmenlerin uygulamalarda yaşadığı sorunlardan dolayı uzman desteğine ihtiyaç duyduğu alanyazında da belirtilmiştir (Gök ve Erbaş, 2011). Bundan dolayı öğretmenlere yardımcı olabilecek ek destekleri sağlamak onları eğitim-öğretim sürecinde güçlendirebilir (Mastropieri, Scruggs ve Mills, 2011). Özel eğitim öğretmenlerinin yanısıra bugün bütün branşlardaki öğretmenlerin eğitim hayatında ve iş hayatında öğrendiği bilgileri kuramdan uygulamaya aktarma sırasında yetersiz kalmasından dolayı ek desteklere ve eğitimlere ihtiyaç duyduğu bilinmektedir (Álvarez Álvarez, 2015; Özçınar ve Deryakulu, 2011; Yıldırım, Ünsal ve Tolunay, 2015). Öğretmenlerin ifadeleri incelendiğinde yaptıkların işin yoğunluğu, kâğıt işleri ve kurumların isteklerinin de onları zorladığı ortaya çıkmıştır. Alan yazında da özel eğitim öğretmenlerini bu tür evrak işlerinin zorladığı belirtilmiştir (Özyürek, 2008; Morrison, 2010). Bu durumlar göz önünde alındığında, danışman/uzman sistem bileşeni kapsamında eklenecek, uzmanların hazırladığı video ve yazıların, kuram ve uygulama arasında bağ kurmada zorluk yaşayan öğretmenler için çocuğun herhangi bir becerisinin izlenmesi veya raporlanması sürecinde öğretmenlerin performansını destekleyebileceği ileri sürülebilir. Böylece öğretmenler bir beceri ile ilgili değerlendirme yaparken uzmanların bu süreci nasıl yürüttüklerini ilgili video ve yazılara EPDS üzerinden ulaşabilirler. Böyle bir sistem aracılığıyla bir yandan öğretmenlerin performansları desteklenirken diğer yandan evrak işlerinde öğretmenlere kolaylık sağlayacağı ileri sürülebilir. Öğretmenlerin teknoloji kullanım durumları incelendiğinde deneyimsiz oldukları hem öğretmen hem de yöneticiler tarafından ifade edilmiştir. Bu anlamda öğretimsel sistem bileşeninin özellikle teknoloji kullanım becerisi düşük kullanıcılara daha çok katkı sağlayacağı ifade edilebilir. Sistemin nasıl kullanılacağı ile ilgili hazırlanan simülasyon, yönerge veya öğretici başlangıçların kullanıılara öğrendiklerini uygulamada yardımcı olacağı alanyazında belirtilmiştir (Raybould, 1990; McKay ve Wager, 2007). Nitekim alanyazın incelendiğinde, Paschall (2004)'ın yaptığı çalışmada veri girişi ve aracın nasıl kullanılacağı konusunda kullanıcıların zaman kaybı yaşadığı ortaya

| Kastamonu Eğitim Dergisi, 2020, Vol. 28, No. 3| 
çıkmıştır. Öğretimsel sistem bileşeni kapsamında sistemin nasıl kullanılacağı ile ilgili kullanıcılara sunulacak destek aracılı̆̆ıla bu tür sorunların önüne geçilebilir.

Bulgular incelendiğinde, bu temel iki bileşenin yanı sıra hem kullanıcıların kendi arasında hem de kullanıcılar ile veliler arasındaki iletişimi güçlendirme adına bazı araçların eklenmesinin de uygun olacağına karar verilmiştir. Mesajlaşma, forum ve sık sorulan sorular gibi araçların eklenmesinin iletişim sürecini daha da güçlendireceği ileri sürülebilir. Bu bileşenlerin eklenmesi ile hem öğretmenlerin kendi aralarındaki hem de öğretmen-veli iletişiminin güçlendirilebileceği beklenmektedir.

Kâğıt prototip kullanılabilirlik çalışmasında, kullanılabilirliğin değerlendirilmesinde verimlilik, etkililik ve memnuniyet olmak üzere üç temel boyuttan etkililik boyutu ile ilgili olarak tasarım hataları için öneriler ve çözüm yolları üretilmeye çalışılmıştır. Katılımcıların böyle bir sistemi gelecekte kullanma niyetlerinin olması ve bu sistemden memnun olmaları da kullanılabilirlik açısından memnuniyet boyutu ile ilgili bir bulgu olarak dikkati çekmektedir. Verimlilik boyutu ile ilgili gerçek sistem üzerinden görev sürelerinin daha düzenli bir şekilde tutulması ve buna yönelik verilerin toplanmasının daha uygun olabileceği düşünülmektedir. Bu açıdan bakıldığında bu çalışma sonucunda ortaya çıkan iki önemli tasarım değişikliğinin de verimliliği etkileyeceği ileri sürülebilir. Özellikle öğrenci ad-soyad aratma durumunun görevlerin sürelerini etkileyeceği ve sistemin verimliliğini etkileyeceği ileri sürülebilir.

Alanyazın incelendiğinde kâğıt prototiplemenin bir ürün geliştirme aşaması başlarında ürünün zayıflıklarını tespit etmede ve tasarım iyileştirmeleri için uygun öneriler sunmada kolaylık sağladığı ifade edilmiştir (Tao ve Or, 2012). Bu anlamda bu çalışmada da kâğıt prototip kullanılabilirliği sistemle ilgili iki önemli tasarımsal hatanın görülmesine katkı sağlamıştır. Tasarım hatalarının çözümü için katılımcıların görevleri başarma durumları ve izledikleri adımlar incelenerek öneriler getirilmiştir. Görevleri başarma durumları incelenirken; bazı hataların kâğıt prototipten kaynaklandığı, gerçek bir sistem tasarlandığında katılımcıların böyle bir hataya düşmelerinin sistem tarafından kolaylıkla engellenebileceği öngörülmüştür. Katılımcıların görevler sırasında öğrenci adını belirtmeksizin görevin diğer adımlarını tamamlamaları buna örnek olarak gösterilebilir. Gerçek bir sistemde öğrenci adı girilmeden ilerlemek mümkün olmayacağından bu durum eksik görev olarak tanımlanmıştır.

Kâğıt kullanılabilirlik değerlendirmesi sonrasında sistemde yapılacak iki önemli değişiklik aşağıda ifade edilmiştir.

- Katılımcıların birçoğu öğrenci ad-soyad aratma yeri ile genel arama yerini karıştırmışlardır. Genel arama yerinin sağa kaydırılıp küçültülmesinin bu problemi çözebileceği kanaatine ulaşılmıştır. İkinci çözüm yolu olarak değerlendirme sayfalarında (ilk, kaba ve genel değerlendirme) öğrencilerin sayfasının altına alınması ile kullanıcılar değerlendirmesini yapmak istediği öğrenciye tıklayıp kişisel sayfasına eriştiğinde ilgili değerlendirme sayfasına erişebilir. Böylece kullanıcılar, ad-soyad aratmasına gerek kalmaksızın değerlendirme ve rapor alabilirler.

- Katılımcılar ilk değerlendirme ile genel değerlendirme altındaki alanlar arasında karışıklık yaşamıştır. Bunun için butonları alta koymak yerine farklı bir yere butonlar eklenebilir. Sağ taraftaki menüde tek buton koyduktan sonra açılan sayfada üst tarafa tab şeklinde bir menü ile gelişim alanlarının yerleştirilmesinin daha uygun olacağı planlanmıştır. Bir katılımcı genel değerlendirme adının seans değerlendirme olarak değiştirilmesinin bu karışıklığı gidereceğini belirtmiştir.

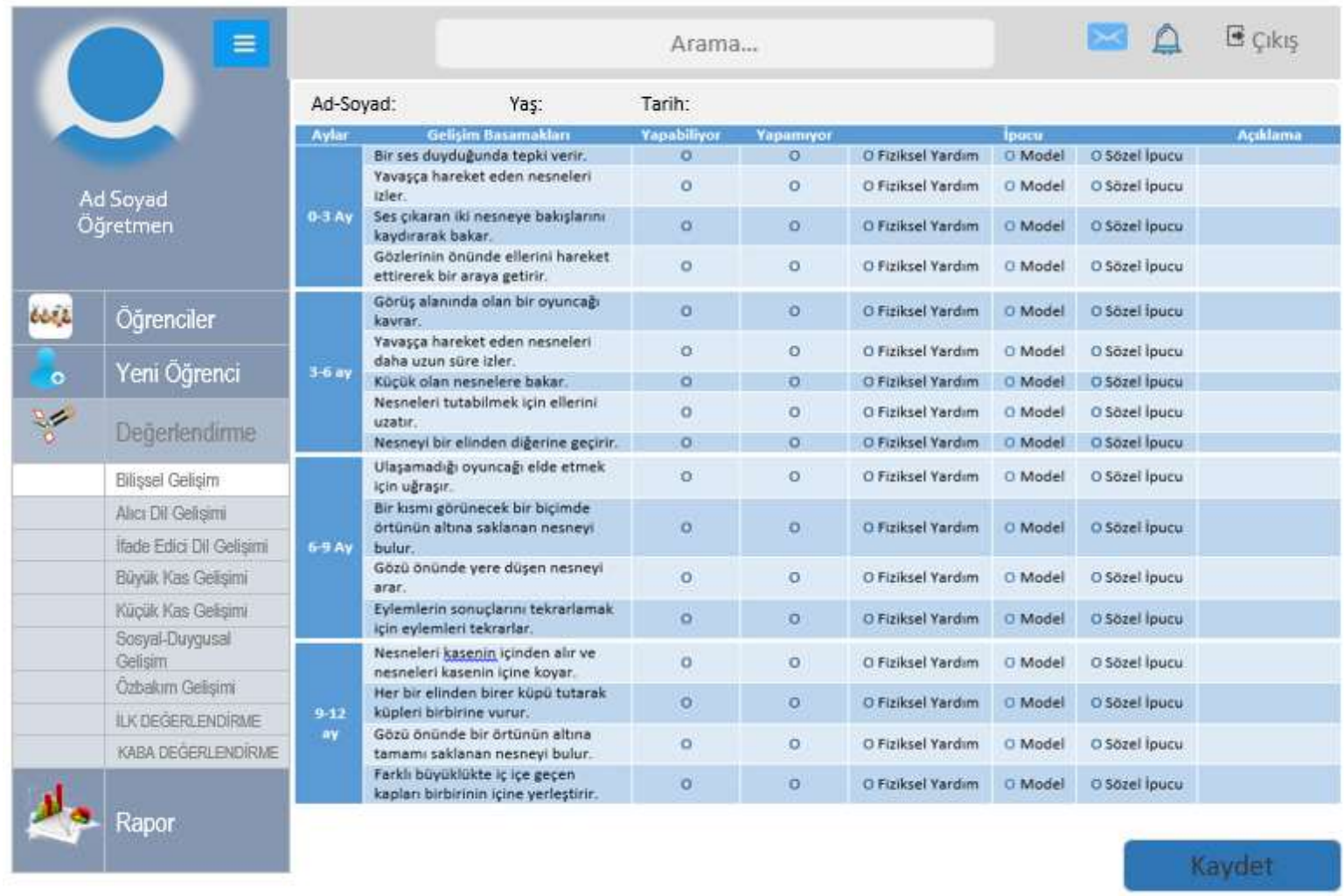

Şekil 4. Kağıt prototip kullanılabilirlik değerlendirmesi yapılmadan sistemin arayüz görünümü 


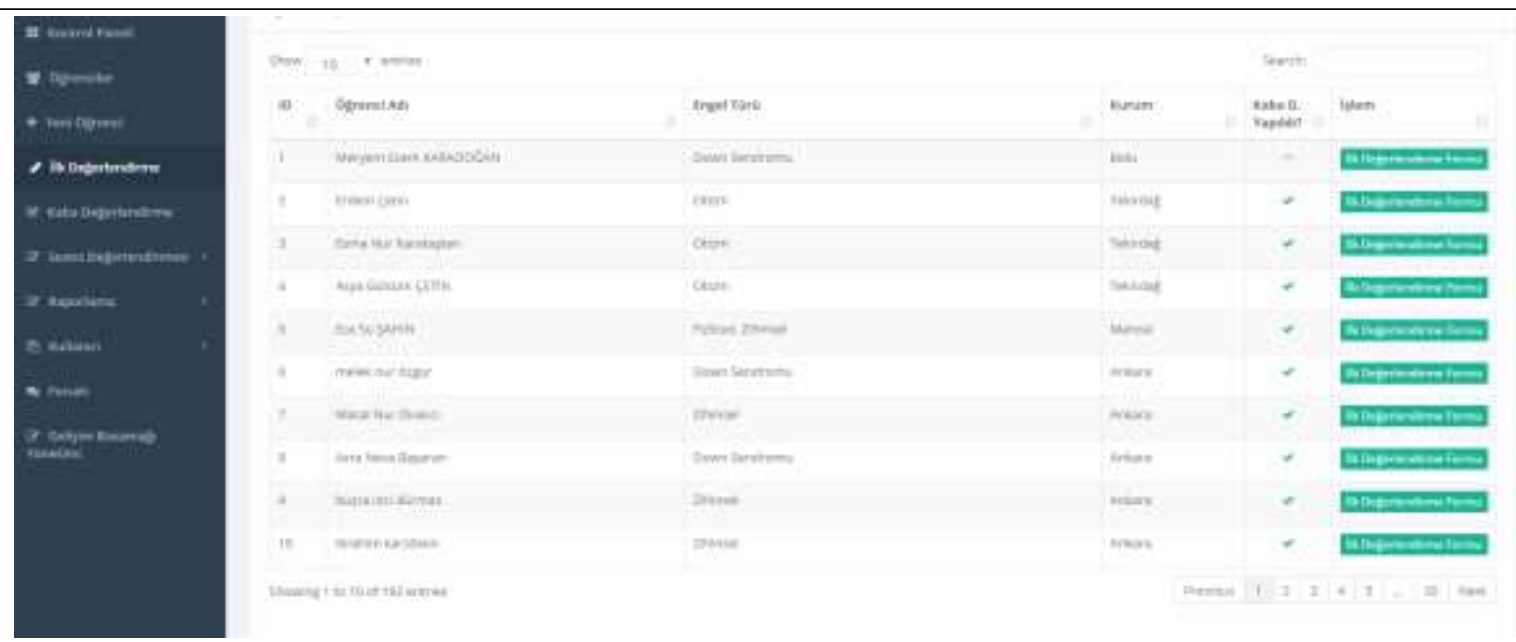

\section{Şekil 5. Kağıt prototip kullanılabilirlik değerlendirmesinden sonra tasarlanması düşünülen sistemin arayüz görünümü}

Şekil 4 ve 5 incelendiğinde genel arama yerinin sağ tarafa alınarak ve öğrenci adı soyadı aratma yerine direk öğrencilerin listelendiği bir sayfa tasarlanmasına karar verilmiştir. Ayrıca sol menüde değerlendirme butonu altında çıkan menü tasarımı yerine ilk, kaba ve seans değerlendirmesi diye farklı bir tasarım ortaya konulmasının uygun olacağı ortaya çıkmıştır. Böylece sol menüde yer alan fazla butonlarla kullanıcıların yaşayabileceği olası karışıklığın giderilmesi hedeflenmektedir.

Ayrıca bulgular incelendiğinde, seans değerlendirmede yapılacak renklendirme değişikliğinin hem raporlama sürecini hem de değerlendirme sürecini kolaylaştıracağı ileri sürülebilir. Kullanıcıların hiç değerlendirme yapmadığı becerilerin kırmızı, başladıkları değerlendirmelerin yeşil, bitirdiği değerlendirmelerin turuncu olarak gösterilmesinin özellikle sistemin verimliliğini etkileyeceği ileri sürülebilir. Kullanıcıların herhangi bir gelişim alanına girdiğinde devam eden veya biten becerileri renklerine göre ayırt edebilmesinin ve beceriye hızlıca ulaşabilmesinin, verimlilikte önemli olan zaman faktörünü etkileyebileceği ileri sürülebilir.

$\mathrm{Bu}$ çalışmada ihtiyaç analizi ve kâğıt kullanılabilirlik değerlendirmesi sonucunda geliştirilmesi düşünülen sistemde bazı değişikliklerin yapılması ve yeni bileşenlerin eklenmesi gerektiği ortaya çıkmıştır. Özellikle EPDS'nin temel bileşenleri arasında olan danışman/uzman sistemi bileşeni içeriğinin nasıl olması gerektiği konusunda bir aşama kaydedilmiştir. Bu anlamda 0-6 yaş arası sistemde var olan becerilerin nasıl değerlendirileceği ile ilgili uzmanların da desteği ile videolar ve bir paragraftan oluşan yazılar hazırlanacaktır. Bu video ve yazılar ilk ve seans değerlendirme sayfalarında nasıl değerlendirme yapılır sütunu altında her bir becerinin yanına eklenecektir. Böylece özellikle yeni başlamış veya farklı branşlardan gelen özel eğitim öğretmenlerine, bir beceri ile ilgili değerlendirme yaparken kolayca ulaşabilecekleri bir destek olarak sunulacaktır. Danışman/uzman sistem bileşeni sadece yeni başlamış öğretmenler için değil aynı zamanda tecrübeli öğretmelere de eklenen videolar sayesinde bir değerlendirme sırasında hatırlatıcı veya farklı yolları gösteren bir bileşen olabilir. Bu anlamda deneyimli öğretmenler içinde faydalı olacağı ifade edilebilir. EPDS'nin bir diğer önemli bileşeni olan öğretimsel sistem bileşeni ile ilgili olarak da sistemin sağ üst köşesine yardım sayfası altında bütün menüler ve kullanıcıların sistem üzerinde yapacağı bütün işlemler ile ilgili kısa videoların eklenmesi düşünülmektedir. Bu anlamda kullanıcıların yapmakta zorlandığı herhangi bir işlem ile ilgili görsel olarak destek alabileceği bir alan oluşturulmasına gereksinim olduğu ortaya çıkmıştır.

Bu çalışmada otantik kişiler ve uzman tasarımcılar ile birlikte bir EPDS taslağı oluşturulmuş ve kâğıt prototip kullanılabilirlik değerlendirmesi yapılarak, erken çocukluk özel eğitimine yönelik erken müdahale konusunda geliştirilmesi düşünülen sistemin tasarım aşamasının temeli oluşturulmuştur. Böylece, EPDS'de bulunması gereken kritik bileşenler ve bu bileşenlerde hangi ögelerin yer alacağı belirlenerek, geliştirilmesi devam eden EPDS’nin bir sonraki döngüsünde nelere gereksinim olduğu konusunda anlamlı verilere ulaşılmıştır.

Bu çalışma sürecinde elde edilen deneyimler ışığında araştırmacıların tasarım geliştirme sistematiğini net bir şekilde ortaya koymaları, özellikle EPDS'nin bileşenlerinin içerikleri konusunda uzmanların da içerisinde olduğu bir ekip ile bu süreci tamamlamaları önerilmektedir. Ortaya çıkan öneriler ve sorunları göz ardı etmeden, bunlara yönelik çözümler üretip sistemde yapılacak her değişiklikten sonra kullanıcı görüşlerinin alınmasının, tasarım ve geliştirme sürecinin daha düzenli bir şekilde ilerlemesine katkı sağlayacağı ifade edilebilir.

\section{KAYNAKÇA}

Álvarez Álvarez, M. D. C. (2015). Can Teachers Bridge the Theory-Practice Gap? An Ethnographic Study of a Teacher. US-China Education Review $B, 5$ (4), 233-244.

Andreassen, R. ve Braten, I. (2013). Teachers' source evaluation self-efficacy predicts their use of relevant source features when evaluating the trustworthiness of web sources on special education. British Journal of Educational Technology, 44(5), 821-836.

Avcıoğlu, H. (2013). Effectiveness of Video Modelling in Training Students with Intellectual Disabilities to Greet People When They Meet. Kuram Ve Uygulamada Eğitim Bilimleri, 13(1), 466-477. 
Barker, P. ve Banerji, A. (1995). Designing Electronic Performance Support Systems. Innovations in Education and Training International. 32(1), 4-12.

Boling, E. ve Frick, T. (2002). Practical web development: A systematic process. Erişim tarihi: 11.10.2017, http://www.indiana.edu/ pedagogy/preview/pwd/.

Brock, M. E. ve Carter, E. W. (2015). Effects of a Professional Development Package to Prepare Special Education Paraprofessionals to Implement Evidence-Based Practice. Journal of Special Education, 49(1), 39-51.

Budak, V. Ö. (2016). Kurumsal bir mobil web sitesinin kullanılabilirliğinin değerlendirilmesi: kırklareli üniversitesi örneği. (Yayınlanmamış Yüksek Lisans Tezi). İstanbul Üniversitesi Fen Bilimleri Enstitüsü, İstanbul.

Buzhardt, J., Walker, D., Greenwood, C. R. ve Heitzman-Powell, L. (2012). Using Technology to Support Progress Monitoring and Data-Based Intervention Decision Making in Early Childhood: Is There an App for That?. Focus On Exceptional Children, 44(8), 1.

Cabielles-Hernández, D., Pérez-Pérez, J. R., Paule-Ruiz, M., \& FernándezFernández, S. (2017). Specialized intervention using tablet devices for communication deficits in children with autism spectrum disorders. IEEE Transactions on Learning Technologies, 10(2), 182-193.

Campigotto, R., McEwen, R. ve Epp, C. D. (2013). Especially social: Exploring the use of an iOS application in special needs classrooms. Computers \& Education, 60(1), 74-86.

Chang, C. C. (2004). The relationship between the performance and the perceived benefits of using an electronic performance support system (EPSS). Innovations in education and teaching international, 41(3), 343-364.

Coleman, M. B., Cramer, E. S., Park, Y., \& Bell, S. M. (2015). Art educators' use of adaptations, assistive technology, and special education supports for students with physical, visual, severe and multiple disabilities. Journal of Developmental and Physical Disabilities, 27(5), 637-660.

Coogle, C. G., Rahn, N. L. ve Ottley, J. R. (2015). Pre-service teacher use of communication strategies upon receiving immediate feedback. Early Childhood Research Quarterly, 32, 105-115.

Creech-Galloway, C., Collins, B. C., Knight, V. ve Bausch, M. (2013). Using a Simultaneous Prompting Procedure With an iPad to Teach the Pythagorean Theorem to Adolescents With Moderate Intellectual Disability. Research and Practice for Persons with Severe Disabilities, 38(4), 222-232.

Cullen, J., Richards, S. B., \& Frank, C. L. (2008). Using software to enhance the writing skills of students with special needs. Journal of Special Education Technology, 23(2), 33-44.

Çağıltay, K. (2006). Scaffolding strategies in electronic performance support systems: Types and challenges. Innovations in education and Teaching International, 43(1), 93-103.

Çağıltay, K. (2011). Insan bilgisayar etkileşimi ve kullanılabilirlik mühendisliği: Teoriden pratiğe. Ankara: ODTÜ Geliştirme Vakfı.

Çağıltay, K. (2016). İnsan bilgisayar etkileşimi ve öğretim teknolojileri. Kürşat Çağıltay, Yüksel Göktaş (Ed.), Öğretim Teknolojilerinin Temelleri (s. 297-312). Ankara: Pegem.

Çıralı, H., Özgür, A., Olgun, S. ve Tüzün, H. (2012). Kâğıt prototip kullanılabilirlik çalışması: Hacettepe üniversitesi eğitim fakültesi akademik özgeçmiş sistemi örneği. 6. Uluslararası Bilgisayar ve Öğretim Teknolojileri Sempozyumunda sunulan bildiri, Gaziantep.

Dix, A., Finlay, J. Abowd, G. ve Beale, R., (2004). Human-computer interaction. England: Pearson Education Limited.

Dix, A. (2009). Human-computer interaction. L. Liu ve M. T. Özsu, Encyclopedia of database systems (ss. 1327-1331). Springer US.

Efevbera, Y., McCoy, D. C., Wuermli, A. J. ve Betancourt, T. S. (2017). Early Childhood Development Plus Violence Prevention in Low-and MiddleIncome Countries: A Qualitative Study. Children \& Society, 31(2), 98-109.

Ekici, M., Arslan, İ., Tüzün, H. (2016). Eğitim Bilişim Ağı (EBA) Web Portalı Kullanılabilirliğinin Göz İzleme Yöntemiyle Değerlendirilmesi. A. İşman, H. F. Odabaşı ve B. Akkoyunlu (Ed.) Eğitim teknolojileri okumaları 2016 (273-296). Ankara: TOJET.

Falth, L., Gustafson, S., Tjus, T., Heimann, M. ve Svensson, I. (2013). Computer-assisted Interventions Targeting Reading Skills of Children with Reading Disabilities - A Longitudinal Study. Dyslexia, 19(1), 37-53.

Gery, G. (1991). Electronic performance support systems: How and why to remake the workplace through the strategic application of technology. Boston: Weingarten.

Gök, G. ve Erbaş, D. (2011). Okul öncesi eğitimi öğretmenlerinin kaynaştırma eğitimine ilişkin görüşleri ve önerileri. International Journal of Early Childhood Special Education, 3(1), 66-87.

Hollingsworth, H. L. ve Lim, C.I. (2015). Instruction Via Web-Based Modules in Early Childhood Personnel Preparation: A Mixed-Methods Study of Effectiveness and Learner Perspectives. Early Childhood Education Journal, 43(2), 77-88.

Hong, E. R., Ganz, J. B., Gilliland, W. ve Ninci, J. (2014). Teaching caregivers to implement an augmentative and alternative communication intervention to an adult with ASD. Research in Autism Spectrum Disorders, 8(5), 570-580.

Hung, W. C., \& Lockard, J. (2007). Using an advance organizer guided behavior matrix to support teachers' problem solving in classroom behavior management. Journal of Special Education Technology, 22(1), 21-36.

Ismaili, J. ve E. O. Ibrahimi (2017). Mobile learning as alternative to assistive technology devices for special needs students. Education and Information Technologies 22(3), 883-899.

ISO 9241-11. (2017). Ergonomics requirements for office with visual display terminals (VDTs) - Part 11: Guidance on usability. Geneva: International Organization for Standardization (ISO). Erişim tarihi: 13.10.2017, https://www.iso.org/obp/ui/\#iso:std:iso:9241:-11:ed2:v1:en

Karal, H. (2009). Evaluating the Impact of Computer Aided Learning Material on Articulation Disorders. Egitim Arastirmalari-Eurasian Journal of Educational Research, 8(34), 55-74. 
Kennedy, M. J., Thomas, C. N., Aronin, S., Newton, J. R. ve Lloyd, J. W. (2014). Improving teacher candidate knowledge using content acquisition podcasts. Computers \& Education, 70, 116-127.

Lee, L. W., Mohamed, A. R. ve Altamimi, A. A. (2015). Design, Development, and Evaluation of an Automated e-Learning Tutorial System to Instruct Pre-Service Special Educators in the Malay Braille Code. Asia-Pacific Education Researcher, 24(3), 481-494.

Marino, M. T. ve Beecher, C. C. (2010). Conceptualızıng rtı in 21st-century secondary science classrooms: video games' potentıal to provıde tiered support and progress monıtorıng for students with learnıng dısabılıtıes. Learning Disability Quarterly, 33(4), $299-311$.

Mason, R. A., Ganz, J. B., Parker, R. I., Boles, M. B., Davis, H. S., \& Rispoli, M. J. (2013). Video-based modeling: Differential effects due to treatment protocol. Research in Autism Spectrum Disorders, 7(1), 120-131. doi: 10.1016/j.rasd.2012.08.003

Mastropieri, M. A., Scruggs, T. E. ve Mills, S. (2011). Special education teacher preparation. J. M. Kauffman ve D. P. Hallahan (Ed.), Handbook of special education (s. 47-58) içinde. New York: Routledge.

Menzi-Cetin, N., Alemdağ, E., Tüzün, H., \& Yıldız, M. (2017). Evaluation of a university website's usability for visually impaired students. Universal Access in the Information Society, 16(1), 151-160.

McKay, J. ve Wager W.W. (2007). Electronic Performance Support Systems: Visions and Viewpoints. Erişim tarihi: 11.10.2017, https://www.mahara.at/artefact/file/download.php?file=190645\&view=30317

Mitchem, K. J., Fitzgerald, G., Miller, K., \& Hollingsead, C. (2013). Using Electronic Performance Support Systems to Improve Academic Performance of Secondary Students with Disabilities. Journal of Special Education Technology, 28(3), 1-20.

Mitchem, K., Kight, J., Fitzgerald, G., Koury, K., \& Boonseng, T. (2007). Electronic performance support systems: An assistive technology tool for secondary students with mild disabilities. Journal of Special Education Technology, 22(2), 1-14.

Morrison, N. J. (2010). The effects of induction, mentoring and local school culture on retention of beginning special education teachers (Doktora Tezi). (http://mars.gmu.edu/jspui/bitstream/handle/1920/5802/Microsoft\%20Word\%20-\%20Morrison\%20diss\%20final\%204-1610.pdf?sequence $=1 \&$ isAllowed=y)

Nielsen, J. (1993). Usability engineering, London: Academic Press.

Nielsen, J. (2000). Why You Only Need to Test with 5 Users. Erişim tarihi: 15.9.2017, http://www.useit.com/alertbox/20000319.html

Norman, K. L. ve Panizzi, E. (2005). Levels of automation and user participation in usability testing. Interacting with computers, 18(2), $246-264$.

Özçınar, H., \& Deryakulu, D. (2011). Video-durumlarda yansıma noktalarının ve tartışma gruplarında öğretmen katılımının yansıtıcı düşünmeye etkisi. Hacettepe Üniversitesi Eğitim Fakültesi Dergisi, 40(40), 321-331.

Özyürek, M. (2008). Nitelikli öğretmen yetiştirmede sorunlar ve çözümler: Özel eğitim örneği. Türk Eğitim Bilimleri Dergisi, 6(2), $189-226$.

Paschall Jr, E. D. (2004). An evaluation of an electronic performance support system implementation (Yayımlanmamış Doktora Tezi). The Florida State University College of Education, Florida.

Pero, K. (2003). Why Usability is Key to Success Online. Erişim tarihi: 17.05.2018, http://www.usableinterface.com/articles/whyusability.php

Ploessl, D. M. ve Rock, M. L. (2014). eCoaching: The Effects on Co-Teachers' Planning and Instruction. Teacher Education and Special Education, 37(3), 191-215.

Polat, E., Adıgüzel, T. ve Akgün, O. E. (2012). Adaptive Web-Assisted Learning System for Students with Specific Learning Disabilities: A Needs Analysis Study. Kuram Ve Uygulamada Ĕgitim Bilimleri, 12(4), 3243-3258.

Rante, H., Schelhowe, H., \& Lund, M. (2016). Paper prototyping for BatiKids: A technique to examine children's interaction and feedback in designing a game-based learning. In Proceedings of Second International Conference on Electrical Systems, Technology and Information 2015 (ICESTI 2015), $\quad$ Singapore. Erişim Adresi: https://www.researchgate.net/publication/297736499_Paper_Prototyping_for_BatiKids_A_Technique_to_Examine_Children\%27s_Int eraction_and_Feedback_in_Designing_a_Game-Based_Learning

Rama, I. ve Kontu, E. (2012). Searching for pedagogical adaptations by exploring teacher's tacit knowledge and interactional co-regulation in the education of pupils with autism. European Journal of Special Needs Education, 27(4), 417-431.

Raybould, B. (1990). Solving human performance problems with computers. A case study: Building an electronic performance support system. Performance and Instruction, 29(10), 4-14.

Reigeluth, C. M.(1999). Personal communication in EPSS, Bloomington, IN: Study Group.

Rock, M. L., Schumacker, R. E., Gregg, M., Howard, P. W., Gable, R. A. ve Zigmond, N. (2014). How Are They Now? Longer Term Effects of eCoaching Through Online Bug-In-Ear Technology. Teacher Education and Special Education, 37(2), 161-181.

Rubin, J., ve Chisnell, D. (2008). Handbook of Usability Testing, Wiley Publishing, Indianapolis.

Sazak-Pınar E., (2006). Dünyada ve Türkiye'de erken çocukluk özel eğitiminin gelişimi ve erken çocukluk özel eğitim uygulamaları. Ankara Üniversitesi Eğitim Bilimleri Fakültesi Özel Eğitim Dergisi, 7(2), 71-83.

Schmid, R. F., Miodrag, N., \& Francesco, N. D. (2008). A human-computer partnership: The tutor/child/computer triangle promoting the acquisition of early literacy skills. Journal of Research on Technology in Education, 41(1), 63-84.

Shackel, B. (2009). Usability-Context, framework, definition, design and evaluation. Interacting with Computers, 21(5-6), 339-346.

Shneiderman, B. \& Plaisant, C. (2003). Designing the user interface: Strategies for effective human-computer interaction (4th Ed). Reading, MA: Addison-Wesley.

Sucuoğlu, B., Bakkaloğlu, H., Karasu, F. İ., Demir, Ş., \& Akalın, S. (2013). Inclusive preschool teachers: Their attitudes and knowledge about inclusion. International Journal of Early Childhood Special Education, 5(2), 107-128. 
Tao, D., \& Or, C. (2012, December). A paper prototype usability study of a chronic disease self-management system for older adults. In 2012 IEEE International Conference on Industrial Engineering and Engineering Management, Hong Kong. Erişim Adresi: https://ieeexplore.ieee.org/abstract/document/6837946

Usability. (2017). 21.11.2017 tarihinde https://www.usability.gov/ adresinden erişilmiştir.

Vuran, S. ve Gül, S. O. (2012). On-the-job Training of Special Education Staff: Teaching the Simultaneous Prompting Strategies. Kuram Ve Uygulamada Eğitim Bilimleri, 12(3), 2101-2110.

Walker, D., Carta, J. J., Greenwood, C. R. ve Buzhardt, J. F. (2008). The use of individual growth and developmental indicators for progress monitoring and intervention decision making in early education. Exceptionality, 16, 33-47.

Wilder, J., Magnusson, L. ve Hanson, E. (2015). Professionals' and parents' shared learning in blended learning networks related to communication and augmentative and alternative communication for people with severe disabilities. European Journal of Special Needs Education, 30(3), 367-383.

Yeniad, M., Mazman, S. G., Tüzün, H. ve Akbal, S. (2011). Bir Bölüm Web Sitesinin Otantik Görevler ve Göz İzleme Yöntemi Aracılığıyla Kullanılabilirlik Değerlendirmesi. Journal of Kirsehir Education Faculty, 12(2).

Yıldırım, O., Ünsal, N., \& Tolunay, B. (2015). Özel Eğitim Öğretmenlerinin Hizmet İçinde Yetiştirilme Düzeyleri. Abant İzzet Baysal Üniversitesi Eğitim Fakültesi Dergisi, 15, 259-274. 